\title{
Campanian-Eocene dinoflagellate cyst biostratigraphy in the Southern Andean foreland basin: Implications for Drake Passage throughflow
}

\author{
*Peter K. Bijl1', G. Raquel Guerstein², Edgar A. Sanmiguel Jaimes ${ }^{3}$, Appy Sluijs ${ }^{1}$, \\ Silvio Casadio ${ }^{4}$, Víctor Valencia ${ }^{5}$, Cecilia R. Amenábar ${ }^{6}$, Alfonso Encinas ${ }^{7}$
}

\author{
${ }^{I}$ Department of Earth Sciences, Laboratory of Palaeobotany and Palynology, Utrecht University, Heidelberglaan 8, 3584 CS Utrecht \\ The Netherlands . \\ p.k.bijl@uu.nl; A.sluijs@uu.nl \\ ${ }^{2}$ Departamento de Geología, Universidad Nacional del Sur-Instituto Geológico del Sur, CONICET, Av. Alem 1253, cuerpo B'-2 Piso \\ Argentina. \\ raquel.guerstein@uns.edu.ar \\ ${ }^{3}$ Universidad Andres Bello, Facultad de Ingenieria, Autopista Concepción-Talcahuano, 7100 Talcahuano, Chile. \\ geosanmiguel@hotmail.com \\ ${ }^{4}$ Universidad Nacional de Río Negro, Instituto de Investigación en Paleobiología y Geología, Av. Roca 1242, General Roca, Río \\ Negro, Argentina. \\ scasadio@unrn.edu.ar \\ ${ }^{5}$ School of the Environment, Washington State University, Pullman, WA 99163, USA. \\ victorv@email.arizona.edu \\ ${ }^{6}$ Instituto Antártico Argentino-Instituto de Estudios Andinos Don Pablo Groeber-CONICET-Dpto. Ciencias Geológicas, Universidad \\ de Buenos Aires, Intendente Guiraldes 2160, C1428EGA, Ciudad Universitaria, Argentina. \\ cr_amenabar@yahoo.com.ar \\ ${ }^{7}$ Departamento de Ciencias de la Tierra, Facultad de Ciencias Químicas, Universidad de Concepción, Edmundo Larenas 129, casilla \\ 160-C, Concepción, Chile. \\ alfonso.encinas@gmail.com \\ *Corresponding author: p.k.bijl@uu.nl
}

\begin{abstract}
The tectonic opening of the Tasmanian Gateway and Drake Passage represented crucial geographic requirements for the Cenozoic development of the Antarctic Circumpolar Current (ACC). Particularly the tectonic complexity of Drake Passage has hampered the exact dating of the opening and deepening phases, and the consequential onset of throughflow of the ACC. One of the obstacles is putting key regional tectonic events, recorded in southern Patagonian sediments, in absolute time. For that purpose, we have collected Campanian-Eocene sediment samples from the Chilean sector of Southern Patagonia. Using U-Pb radiometric dating on zircons and dinoflagellate cyst biostratigraphy, we updated age constraints for the sedimentary formations, and the hiatuses in between. Thick sedimentary packages of shallowmarine and continental sediments were deposited in the foreland basin during the early Campanian, mid-Paleocene, the Paleocene-Eocene boundary interval and the middle Eocene, which represent phases of increased foreland subsidence. We interpret regional sedimentary hiatuses spanning the late Campanian, early-to mid-Paleocene, mid-Eocene and latest Eocene-early Oligocene to indicate times of reduced foreland subsidence, relative to sediment supply. We relate these changes to varying subduction rates and Andean orogeny. Dinoflagellate cyst assemblages suggest that the region was under the influence of the Antarctic-derived waters through the western boundary current of the Subpolar Gyre, developed in the southwest Atlantic Ocean and thus argues for limited throughflow through the Drake Passage until at least the latest Eocene. However, the proliferation of dinoflagellate endemism we record in the southwest Atlantic is coeval with that in the southwest Pacific, and on a species level, dinoflagellate cyst assemblages are the same in these two regions. This suggests that both regions were oceanographically connected throughout the early Paleogene, likely through a shallow opening of a restricted Drake Passage. This implies a continuous surface-water connection between the south Pacific and the South Atlantic throughout the late Cretaceous-early Paleogene.
\end{abstract}


RESUMEN. Bioestratigrafía de quistes dinoflagelados del Campaniano-Eoceno en la cuenca de antepaís de los Andes meridionales: implicancias para la circulación oceánica a través del Pasaje de Drake. La apertura tectónica del Conducto de Tasmania y del Pasaje de Drake implicó dos requisitos geográficos cruciales para el desarrollo de la Corriente Circumpolar Antártica (CCA) durante el Cenozoico. En particular, la complejidad tectónica del Pasaje de Drake ha dificultado la datación precisa de las fases de apertura y profundización, y el consiguiente inicio del flujo de la CCA. Uno de los problemas es poner en tiempo absoluto los eventos tectónicos regionales claves, registrados en los sedimentos del sur de la Patagonia. Para ese propósito, recolectamos muestras de sedimentos del Campaniano-Eoceno del sector chileno de la Patagonia meridional. Utilizando la datación radiométrica de U-Pb en circones y la bioestratigrafía de quistes de dinoflagelados (dinoquistes), actualizamos los límites de edades de las formaciones sedimentarias, y los hiatos entre ellas. Los espesos paquetes sedimentarios de sedimentos marinos poco profundos y continentales fueron depositados durante el Campaniano temprano, el Paleoceno medio, el límite Paleoceno-Eoceno y el Eoceno medio, que representan fases de mayor subsidencia de la cuenca. Interpretamos la existencia de hiatos sedimentarios regionales que abarcan el Campaniano tardío, el Paleoceno temprano y medio, el Eoceno medio y el Eoceno tardío-Oligoceno temprano para indicar los momentos de menor subsidencia del terreno en relación con el aporte de sedimentos. Vinculamos estos cambios con la variación de las tasas de subducción y la orogenia andina. Las asociaciones de dinoquistes sugieren que la región estaba bajo la influencia de aguas provenientes de la Antártica a través de la corriente de borde occidental del Giro Subpolar desarrollado en el Atlántico sudoccidental y, por lo tanto, argumentan a favor de un flujo limitado a través del Pasaje de Drake hasta por lo menos el Eoceno más tardío. Sin embargo, la proliferación del endemismo de dinoflagelados que registramos en el Atlántico sudoccidental es coetánea con la del Pacífico sudoccidental, y a nivel de especies, se caracterizan por las mismas asociaciones de dinoquistes. Esto sugiere que ambas regiones estaban conectadas durante el Paleógeno temprano, probablemente a través de una apertura somera en un Pasaje de Drake limitado. Esto implica una conexión continua de agua superficial entre el Pacífico Sur y el Atlántico Sur durante el Cretácico tardíoPaleógeno temprano.

Palabras clave: Quistes de dinoflagelados, Bioestratigrafía, Datación radiométrica, Pasaje de Drake, Paleoceanografia, Endemismo.

\section{Introduction}

The Antarctic Circumpolar Current (ACC), the largest and strongest ocean current on our planet, is one of the main drivers of global deep ocean circulation and mid- to high latitude climate of the southern hemisphere (Orsi et al., 1995). It remains unclear when the ACC first developed, attained its present-day strength and how its evolution influenced Antarctic and global climates (e.g., Barker et al., 2007). The continental conduit at Drake Passage (Fig. 1) was a major geographical barrier that prevented circumpolar ocean circulation for a large portion of the Cenozoic (Barker and Thomas, 2004), and as such has long represented a key study area to understand the development of the ACC (e.g., Sijp et al., 2014). Several challenges prevent a clear understanding the timing and evolution of the opening of Drake Passage. First, the Drake Passage area represents a series of oceanic basins, spreading- and subduction zones and continental micro-blocks, which makes tectonic restoration a complex puzzle (Lagabrielle et al., 2009; Pérez et al., 2019). Second, these micro-blocks likely underwent a series of submersion and uplifting phases, which makes recurring obstruction and re-opening of Drake Passage a possibility. Third, the sedimentary sequences that document the tectonic evolution of the region are notoriously difficult to date: carbonate and silica microfossils are not well preserved.

The Scotia Sea separates the Antarctic Peninsula from South America (Fig. 1) and contains several (at present-day) submerged continental blocks that were separated from the American and west-Antarctic plates in the process of rifting. Between these blocks, oceanic crust formed along a number of mid-ocean ridges (Lagabrielle et al., 2009; Pérez et al., 2019). Continental extension likely started prior to the earlymiddle Eocene boundary ( $49 \mathrm{Ma}$; Livermore et al., 2005; Lagabrielle et al., 2009) and ocean crust formed from the late Eocene onwards (Eagles and Livermore, 2002). These tectonic reconstructions provide little constraint on the bathymetric depths of submerged continental blocks, and therefore the question remains whether or not there was shallow ocean throughflow during the Cretaceous-early Paleogene.

As an alternative approach, oceanographic changes around Drake Passage have been investigated as a "smoking gun" for Drake Passage opening and onset of the ACC. Scher and Martin (2006) suggested bottom water connectivity between the South Atlantic and South Pacific from $41 \mathrm{Ma}$ onwards based on Neodymium isotope ratios. Whilst such reconstructions 


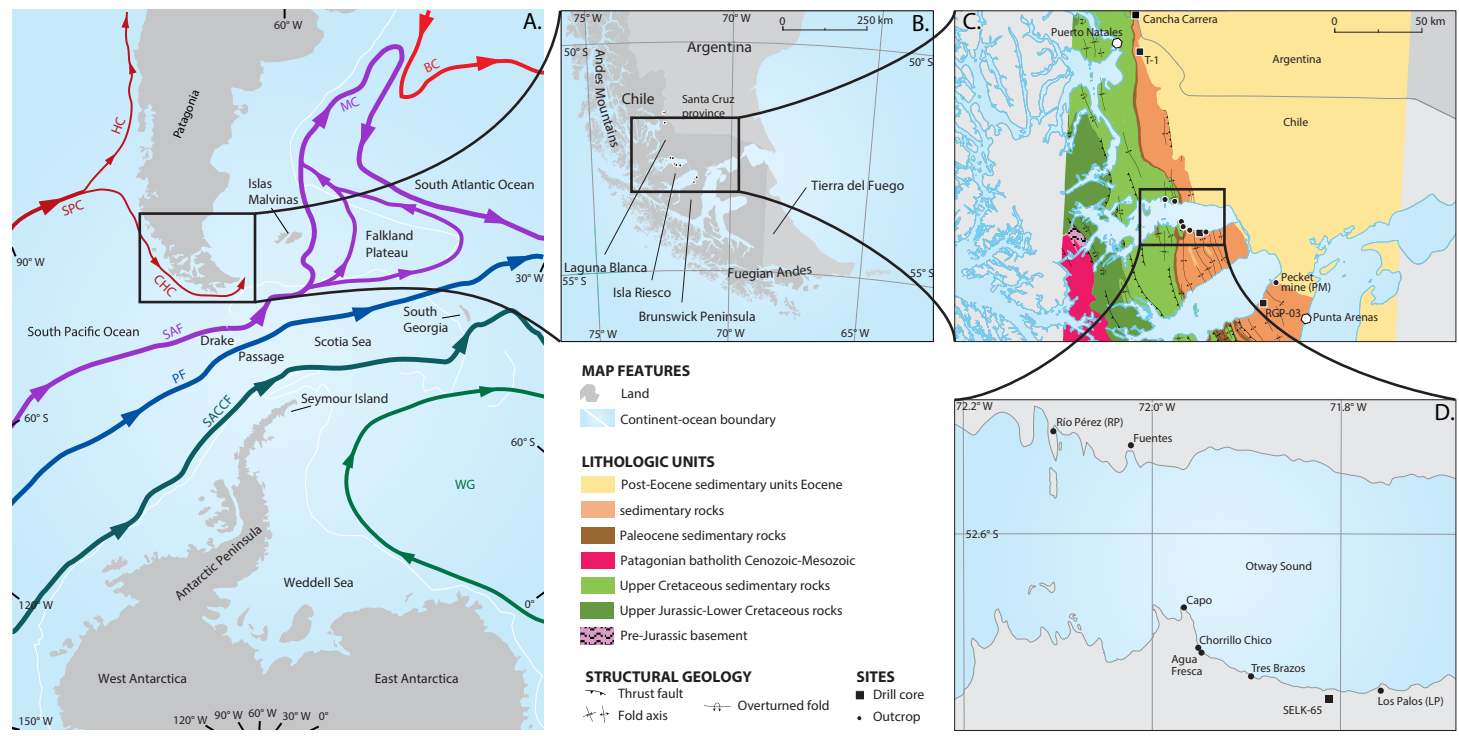

FIG. 1. Location map of studied sites. A. Geographic map of the Drake Passage area. White lines depict continent-ocean boundaries. Colored lines schematically depict prevailing ocean surface currents. WG: Weddell Gyre, SACCF: Southern ACC Front, PF: Polar Front, SAF: Subantarctic Front, CHC: Cape Horn Current, HC: Humboldt Current, SPC: South Pacific Current, MC: Malvinas Current, BC: Brazil Current. B. Detailed map of Southern Patagonia and Tierra del Fuego. C. Detailed map of the Brunswick Peninsula area, showing lithostratigraphic units and geologic structures (based on Sernageomin, 2003). D. Detailed map of the Otway Sound area, showing the localities of the sample sites on North shore of Isla Riesco and Fuentes/ Río Pérez outcrops.

do not reach beyond the mid-Eocene, more recent tectonic studies do interpret renewed compression in the Drake Passage region during the Oligocene (Lagabrielle et al., 2009), with potential for temporal restriction of the Drake Passage following initial Eocene opening. Indeed, while oceanic basins existed in the Scotia Sea since the late Eocene, the greatest unknown, and crucial for an unrestricted flow of an incipient ACC, is the height and exact position of the continental micro-blocks that formed a barrier. This leaves the details of Drake Passage opening as yet poorly understood.

Studies on the Tasmanian Gateway have shown the potential of dinoflagellate cyst-based oceanographic reconstructions for understanding the history of Southern Ocean gateways (e.g., Huber et al., 2004; Bijl et al., 2011). Dinoflagellate cysts show strict provincialism on either side of the Tasmanian Gateway prior to opening: cosmopolitan and lowlatitude derived assemblages west of the Gateway, in the Australo-Antarctic Gulf (Brinkhuis et al., 2003a; Bijl et al., 2011; Houben et al., 2019) and Antarctic-endemic assemblages in the southwest Pacific, east of the Gateway (Bijl et al., 2011, 2013a).
The continued widening of the Australo-Antarctic Gulf allowed eastward progression of the protoLeeuwin Current towards the still closed Tasmanian Gateway (Sauermilch et al., 2019). The earliest signs of Tasmanian Gateway opening come from the appearance of endemic dinoflagellate cyst species on the Antarctic margin on the western side of the gateway, which indiciates throughflow of a westward counter current along the Antarctic margin into the Australo-Antarctic Gulf by the end of the early Eocene, 49 Ma (Bijl et al., 2013a). Coarseresolution ocean model simulations suggest that this westward counter current was relatively weak and only present with a closed Drake Passage (Sijp et al., 2016), although this result is strongly dependent on the insufficiently constrained regional geographic and climatic boundary conditions.

A second phase of opening widened and seemingly deepened the Tasmanian Gateway from around $35 \mathrm{Ma}$ onwards, which had great consequences for regional ocean current configuration. Throughflow of a proto-ACC was induced (Sluijs et al., 2003; Stickley et al., 2004), and surface currents accelerated (Houben et al., 2019). Numerical model simulations 
by Sijp et al. (2016) suggest this could only have occurred if Drake Passage was sufficiently deep as well ( $\sim 350 \mathrm{~m}$ in the model simulation). Thus, these simulations imply that with both gateways open, the subpolar cyclonic gyres were disrupted by an incipient unrestricted ACC and the endemic assemblage became extinct (Huber et al., 2004; Guerstein et al., 2010; Bijl et al., 2011). However, progressive cooling of the Southern Ocean may have played an additional role (Houben et al., 2019).

With the development of the Tasmanian Gateway now relatively well-constrained, improved understanding is needed of the tectonic developments of Drake Passage. For Drake Passage, however, the microfossil evidence supporting this oceanographic regime is thus far insufficient. Evidence for the oceanographic consequences of Drake Passage opening can only come from sediments from the Atlantic side (e.g., Guerstein et al., 2010, 2014; Houben et al., 2019) and the Antarctic Peninsula (e.g., Douglas et al., 2014; Amenábar et al., 2019), as sediments from the Pacific side have been lost through subduction.

The Andean orogeny has created foreland basins with deep depocentres, and subsequent uplift has exposed these Campanian-Eocene sedimentary successions. Previous work on Eocene outcrops in the Santa Cruz and Tierra del Fuego provinces in the Austral Basin, Argentina, has documented a dominant Antarctic endemic dinoflagellate cyst community during the middle Eocene there as well (Guerstein et al., 2010, 2014; González Estebenet et al., 2016). However, the start of the proliferation of this endemic-Antarctic community in the southwest Atlantic Ocean and how this relates to regional oceanography remain unclear. In addition, the general scarcity of data implies that better spatial coverage of longer and more complete records can shed new light on the details of tectonic and oceanographic developments in the region.

Therefore, we studied a series of shallow-marine late Cretaceous-Eocene rocks from the Chilean Patagonia region. We analyzed outcrop and core samples from three regions: Laguna Blanca region, Isla Riesco and the Brunswick Peninsula (Fig. 1). The sedimentary rocks are from basin depocenters and thus supposedly correspond to the deepest possible depositional settings, where the potential for continuous sedimentation is the highest. We provide a coherent and detailed chronostratigraphic framework for the sequences through dinoflagellate cyst biostratigraphy, taking advantage of the well-calibrated dinoflagellate cyst bioevents for the Southern Ocean (e.g., Bijl et al., 2013b; González Estebenet et al., 2016; Fig. 2), and radiometric dating of zircons. Dinoflagellate cyst assemblages are subsequently used to assess depositional setting (Sluijs et al., 2005; Frieling and Sluijs, 2018) and the degree of endemism (Bijl et al., 2011). This allows us to reconstruct the oceanographic regime in the Southwest Atlantic and compare it to that of Tasmanian region, thereby inferring the oceanographic connectivity through Drake Passage.

\section{Material}

\subsection{Sample collection}

The samples for this study were collected in January 2016. We sampled outcrops and core material in three regions: Laguna Blanca, Isla Riesco and Brunswick Peninsula (Fig. 1; Table 1). For exact locations of our sampling, the global positioning system coordinates are available upon request. We preferentially sampled fine-grained intervals rather than coarse-grained sandstones, in order to optimize chances of well-preserved organic microfossil yields. Sample sites were cleared of weathered material but some influence of post-depositional weathering cannot be excluded. Core material recovered was made available by Ingeniería Civil Vicente (ICV), was photographed prior and after sampling (photos available upon request). We systematically took 3 samples per 1.5 meter-long core section, again with the exception of coarse-grained sandstone intervals. The drilled depth intervals for the cores, as marked on the core boxes and our measurements of the lengths of the core sections indicate that core recovery was very high, with only minimal gaps. We assumed that the top of the recovered core corresponds to the top of the drilled interval. Samples are stored in the collection of the Department of Earth Sciences of Utrecht University.

\subsection{Lithostratigraphic units}

We provide an overview of the lithostratigraphic formations in chronological order and their tentative ages based on earlier work (e.g., Thomas, 1949; Otero et al., 2012; Malumián et al., 2013). Table 2 presents a summary and reference to the localities (Fig. 1) where we sampled these formations. 


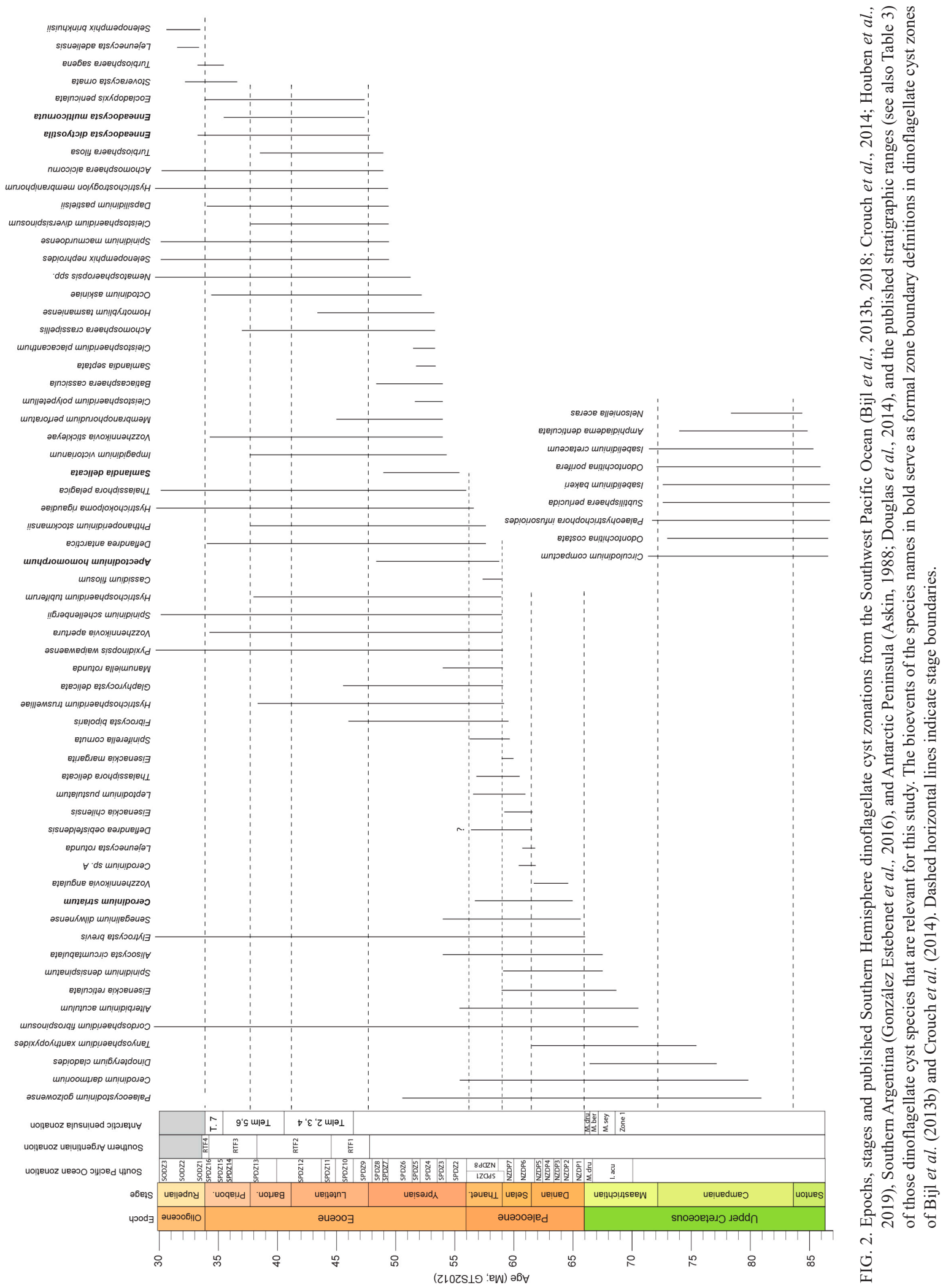


TABLE 1. GEOGRAPHIC LOCATION OF OUTCROPS AND CORES, WITH FORMATION NAMES AND TENTATIVE AGE.

\begin{tabular}{|c|c|c|c|c|c|c|}
\hline Outcrop/core & $\begin{array}{c}\text { \# of samples } \\
\text { analysed for } \\
\text { palynology }\end{array}$ & Region & Formation & Age & Latitude & Longitude \\
\hline Río Pérez Outcrop & 19 & $\begin{array}{l}\text { Laguna } \\
\text { Blanca }\end{array}$ & Chorrillo Chico & Paleocene & $52^{\circ} 32^{\prime} 1.56^{\prime \prime} \mathrm{S}$ & $72^{\circ} 6 ’ 22.41^{\prime \prime} \mathrm{W}$ \\
\hline T-1 Well & 9 & $\begin{array}{l}\text { Laguna } \\
\text { Blanca }\end{array}$ & $\begin{array}{l}\text { Leña Dura and } \\
\text { Loreto }\end{array}$ & middle Eocene & $51^{\circ} 46^{\prime} 18.55^{\prime \prime} \mathrm{S}$ & $72^{\circ} 18^{\prime} 52.30^{\prime \prime} \mathrm{W}$ \\
\hline $\begin{array}{l}\text { Río Los Palos } \\
\text { outcrop }\end{array}$ & 10 & Isla Riesco & Loreto & late Eocene & $52^{\circ} 42^{\prime} 3.66^{\prime \prime} \mathrm{S}$ & $71^{\circ} 45^{\prime} 31.34^{\prime \prime} \mathrm{W}$ \\
\hline SELK-65 Well & 15 & Isla Riesco & Leña Dura & middle Eocene & $52^{\circ} 42^{\prime} 24.20^{\prime \prime} \mathrm{S}$ & $71^{\circ} 48^{\prime} 51.71^{\prime \prime} \mathrm{W}$ \\
\hline Pecket Mine outcrop & 8 & $\begin{array}{l}\text { Brunswick } \\
\text { Peninsula }\end{array}$ & Loreto & $\begin{array}{l}\text { late Eocene- } \\
\text { Oligocene? }\end{array}$ & $52^{\circ} 57^{\prime} 32.96^{\prime \prime} \mathrm{S}$ & $71^{\circ} 9^{\prime} 34.04^{\prime \prime} \mathrm{W}$ \\
\hline RGP-03 Well & 29 & $\begin{array}{l}\text { Brunswick } \\
\text { Peninsula }\end{array}$ & Tres Brazos & early Eocene & $53^{\circ} 3^{\prime} 57.98^{\prime \prime} \mathrm{S}$ & $71^{\circ} 16^{\prime} 7.20^{\prime \prime} \mathrm{W}$ \\
\hline Fuentes outcrop & 2 & $\begin{array}{l}\text { Laguna } \\
\text { Blanca }\end{array}$ & Fuentes & $\begin{array}{l}\text { early } \\
\text { Campanian }\end{array}$ & $52^{\circ} 32^{\prime} 34.26^{\prime \prime} \mathrm{S}$ & $72^{\circ} 1$ '26.77” W \\
\hline IR-CAPO outcrop & 3 & Isla Riesco & Rocallosa & Maastrichtian & $52^{\circ} 38^{\prime} 51.01^{\prime \prime} \mathrm{S}$ & $71^{\circ} 58^{\prime} 4.39^{\prime \prime} \mathrm{W}$ \\
\hline IR-CC outcrop & 5 & Isla Riesco & Chorrillo Chico & Paleocene & $52^{\circ} 40^{\prime} 24.71^{\prime \prime} \mathrm{S}$ & $71^{\circ} 57^{\prime} 9.62^{\prime \prime} \mathrm{W}$ \\
\hline IR-AGFR outcrop & 2 & Isla Riesco & Agua Fresca & $\begin{array}{l}\text { Paleocene- } \\
\text { Eocene }\end{array}$ & $52^{\circ} 40^{\prime} 35.98^{\prime \prime} \mathrm{S}$ & $71^{\circ} 56^{\prime} 57.27^{\prime \prime} \mathrm{W}$ \\
\hline IR-3B outcrop & 2 & Isla Riesco & Tres Brazos & early Eocene & $52^{\circ} 41^{\prime} 30.95^{\prime \prime} \mathrm{S}$ & $71^{\circ} 53^{\prime} 47.61^{\prime \prime} \mathrm{W}$ \\
\hline
\end{tabular}

\subsubsection{Fuentes Formation}

The Fuentes Formation (Hoffstetter et al., 1957; Thomas, 1949) is a thick (up to 1,200 m) succession of platform sediments including shales, glauconitic sandstones with ripples marks and cross-bedding. According to Charrier and Lahsen (1969), García (1952) raised the unit to Formation rank, and distinguished a lower shale, a middle sandstone, and an upper shale. The Fuentes Formation reflects voluminous sediment supply from the Andean orogeny (Charrier and Lahsen, 1969). Published age for the Fuentes Formation is early Maastrichtian (Malumián et al., 2013). The contact with the overlying formation has been a matter of debate: while Thomas (1949) suggested it was clearly non-conformable, Charrier and Lahsen (1969) put this into question. Both studies agree on a sharp lithological transition between both formations.

\subsubsection{Rocallosa Formation}

The Rocallosa Formation (Hoffstetter et al., 1957) raised by Thomas (1949) to the rank of Formation, consists of hard, conglomeritic and coarse sandstone wedges, alternated with intervals of fine shales and siltstones (Charrier et al., 2007). The sediment in the Rocallosa Formation is gradually fining upwards. Zircon dating suggests a late Maastrichtian age (67 Ma; Malumián et al., 2013). A hiatus has been suggested between the Rocallosa and the overlying Chorillo Chico Formation (Malumián et al., 2013).

\subsubsection{Chorrillo Chico Formation}

The Chorrillo Chico Formation (Thomas, 1949) consists of compact, brown indurated claystone, sporadically intercalated with (occasionally glauconitic) sandstone lenses and concretions (Otero et al., 2012). Dinoflagellate cyst biostratigraphy and zircon dating suggest a Thanetian age (58-56 Ma; Quattrocchio, 2009; Malumián et al., 2013).

\subsubsection{Agua Fresca Formation}

The Agua Fresca Formation (Hoffstetter et al., 1957 ) is locally up to $2,000 \mathrm{~m}$ thick, and consists of microfossil-rich light grey mudstones and sandstones (Otero et al., 2012), with concretions and 
TABLE 2. LITHOSTRATIGRAPHIC FORMATIONS IN CHILEAN SOUTHERN PATAGONIA.

\begin{tabular}{|c|c|c|c|c|c|c|c|c|c|c|}
\hline \multirow[b]{2}{*}{ Formation } & \multirow[b]{2}{*}{ Lithology } & \multirow{2}{*}{$\begin{array}{c}\text { Tentative } \\
\text { age } \\
(*)\end{array}$} & \multicolumn{8}{|c|}{ Present in } \\
\hline & & & $\begin{array}{l}\text { Río } \\
\text { Pérez }\end{array}$ & Fuentes & $\begin{array}{l}\text { T-1, } \\
\text { T-22 }\end{array}$ & IR & SELK-65 & $\begin{array}{c}\text { Río } \\
\text { Los } \\
\text { Palos }\end{array}$ & RGP-03 & Pecket \\
\hline Loreto & $\begin{array}{l}\text { Thick cross-bedded } \\
\text { sandstone units, heterolithic } \\
\text { beds, concretions and coal }\end{array}$ & late Eocene & - & - & - & - & - & $\mathrm{X}$ & - & $\mathrm{X}$ \\
\hline $\begin{array}{l}\text { Leña } \\
\text { Dura }\end{array}$ & $\begin{array}{l}\text { Grey shales with marine } \\
\text { macro and micro- } \\
\text { invertebrates }\end{array}$ & middle Eocene & - & - & $\mathrm{X}$ & $\mathrm{X}$ & $\mathrm{X}$ & - & - & - \\
\hline Tres Brazos & $\begin{array}{l}\text { Silt-sandstones with } \\
\text { conglomerate lenses and } \\
\text { coal }\end{array}$ & early Eocene & - & - & - & $\mathrm{X}$ & - & - & $\mathrm{X}$ & - \\
\hline Aqua Fresca & $\begin{array}{l}\text { Microfossil-rich claystones } \\
\text { and sandstones }\end{array}$ & early Eocene & - & - & - & $\mathrm{X}$ & - & - & - & - \\
\hline $\begin{array}{l}\text { Chorillo } \\
\text { Chico }\end{array}$ & $\begin{array}{l}\text { Dark grey claystones, } \\
\text { alternating with green } \\
\text { siltstones. sand lenses and } \\
\text { concretions }\end{array}$ & Paleocene & $X$ & - & - & $\mathrm{X}$ & - & - & - & - \\
\hline Rocallosa & $\begin{array}{l}\text { Hard conglomeritic sands- } \\
\text { tones alternating with minor } \\
\text { heterolithic shales }\end{array}$ & $\begin{array}{l}\text { Late } \\
\text { Cretaceous }\end{array}$ & $\mathrm{X}$ & - & - & $\mathrm{X}$ & - & - & - & - \\
\hline Fuentes & $\begin{array}{l}\text { Alternating dark grey-dark } \\
\text { green shales }\end{array}$ & $\begin{array}{l}\text { Late } \\
\text { Cretaceous }\end{array}$ & - & $X$ & - & & - & - & - & - \\
\hline
\end{tabular}

$(*)$ Their tentative age according to the literature (for reference see text), and the localities (see Fig. 1) where these formations were sampled.

minor glauconite horizons (Malumián et al., 2013). Foraminifer stratigraphy indicates an early Eocene age (56-48 Ma; Malumián et al., 2013). A 3 Myr hiatus has been suggested between the Agua Fresca and Tres Brazos formations (Malumián et al., 2013).

\subsubsection{Tres Brazos Formation}

The Tres Brazos Formation represents eastward prograding delta deposits consisting of glauconitic silt- and sandstones, intercalated with conglomerate lenses and coal seams (Charrier et al., 2007). In some studies (e.g., Otero et al., 2012; Malumián et al., 2013) the Tres Brazos Formation and the Leña Dura Formation are considered one single formation. Age is tentatively mid-Eocene (Malumián et al., 2013).

\subsubsection{Leña Dura Formation}

According to Otero et al. (2012), the Leña Dura Formation (Natland et al., 1974) consists of grey, hard shales, which are rich in marine invertebrate and microfossils, particularly within concretions. Pioneering dinoflagellate cyst stratigraphy by Cookson and Cranwell (1967) suggested a late Eocene age for the formation, which was later adjusted to middle Eocene by Malumián et al. (2013).

\subsubsection{Loreto Formation}

The Loreto Formation (Hoffstetter et al., 1957) was deposited in shallow-marine to terrestrial environments based on the abundance of macrofossils (bivalves, gastropods and vertebrates; Otero et al., 2012) and, increasingly upwards, coal seams (Thomas, 1949). The lithology consists of well-sorted sandstones, heterolithic beds, concretionary horizons. Several coal seams (Otero et al., 2012) indicate an occasional terrestrial depositional environment for the unit. This formation is tentatively dated to be late Eocene (Otero et al., 2012).

\subsection{Laguna Blanca region: sections and samples}

\subsubsection{Río Pérez; Chorrillo Chico Formation}

The outcrop is located on the east coastal cliff of a southward extending peninsula into the Otway Sound (Fig. 1C). We sampled the Chorrillo Chico Formation starting directly above the Rocallosa 
Formation stratigraphically up-section, from $\mathrm{S}$ to N. Strata dip about $30^{\circ}$ NW (Fig. 3). The section is comparatively well exposed, particularly in the storm flood level area. The top of the Chorrillo Chico Formation was not recognized; vegetation overgrowth obscures the sediment exposure towards the top of the section (Fig. 3). Sediments consist of relatively soft shales, alternating grey, green grey and light brown, with occasional harder, sandier levels (Figs. 3, 4).

\subsubsection{Fuentes; Fuentes Formation}

The top of the Fuentes Formation was sampled at a road construction site of road Y-50. Fresh material was collected from a recently blasted outcrop showing vertically dipping, roughly N-S striking $0.5-1 \mathrm{~m}$ thick alternations of greenish grey and dark grey siltstones. The road cut also revealed the boundary between the Fuentes and overlying Rocallosa Formations, which appears very sharp at this location.

\subsubsection{Wells T-1 and T-22; Leña Dura and Loreto formations}

Well T-1 was drilled in the northern part of the Laguna Blanca region in Chile, near the Argentinian border and Puerto Natales (Fig. 1C). The sedimentary rocks correspond to part of the Leña Dura Formation. The sequence consists of siltstone shales, interrupted by two thick sandstone units with conglomerates at the base (Fig. 5). The top part of the recovered sequence contains an $8 \mathrm{~m}$ thick coal layer. We therefore infer that T-1 and T-22 recovered the boundary between the Leña Dura and Loreto formations. A 10 kg sample for zircon radiometric dating was obtained from a core in the T-22 well (not shown), $\sim 250 \mathrm{~m} \mathrm{NE}$ of $\mathrm{T}-1$. The sample corresponds to a medium to coarsegrain sandstone, located just above the same thick coal seam as was recovered at well T-1 (Fig. 5). We sampled cores 1-21 of T-1 at a resolution of $150 \mathrm{~cm}$.

\subsection{Isla Riesco region: sections and samples}

\subsubsection{North-coastal outcrops Isla Riesco; Rocallosa, Chorrillo Chico, Agua Fresca, Tres Brazos formations}

We followed road Y-50 along the north shore of eastern Isla Riesco. The shore features outcrops of Eocene sediments, which are close to horizontal, with some gentle E-W compressional folding (Fig. 1C, D). As a result of this, and because of the abundance of vegetation overgrowth, the stratigraphic thickness of the Eocene deposits is difficult to establish with precision and therefore the stratigraphic height of the samples (Supplement 1) should be considered a rough estimate. The few outcrops along this shore consisted of $<1 \mathrm{~m}$ high storm wave-induced cliff faces where we were able to sample exposures corresponding to the Rocallosa (CAPO), Chorrillo Chico (CC), Agua Fresca (AGFR), Tres Brazos (3B)

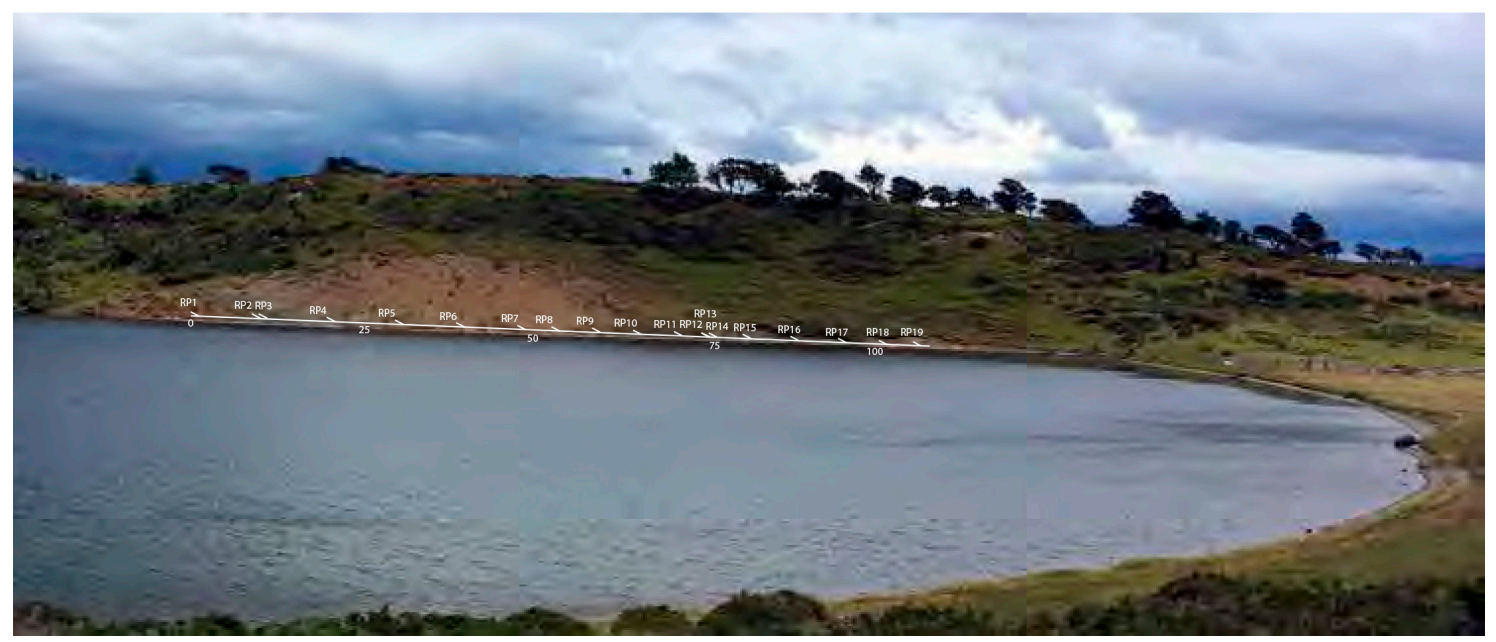

FIG. 3. Photograph showing part of the Chorrillo Chico Formation, at the sampled Río Pérez section, Laguna Blanca region, Chile (see Fig. 1 for locality). Image was taken towards the west. Horizontal scale: section approx. $200 \mathrm{~m}$. The position of samples used in this study are indicated above the white line, number below the white line indicate stratigraphic height $(\mathrm{m})$ above thick sandstone. 


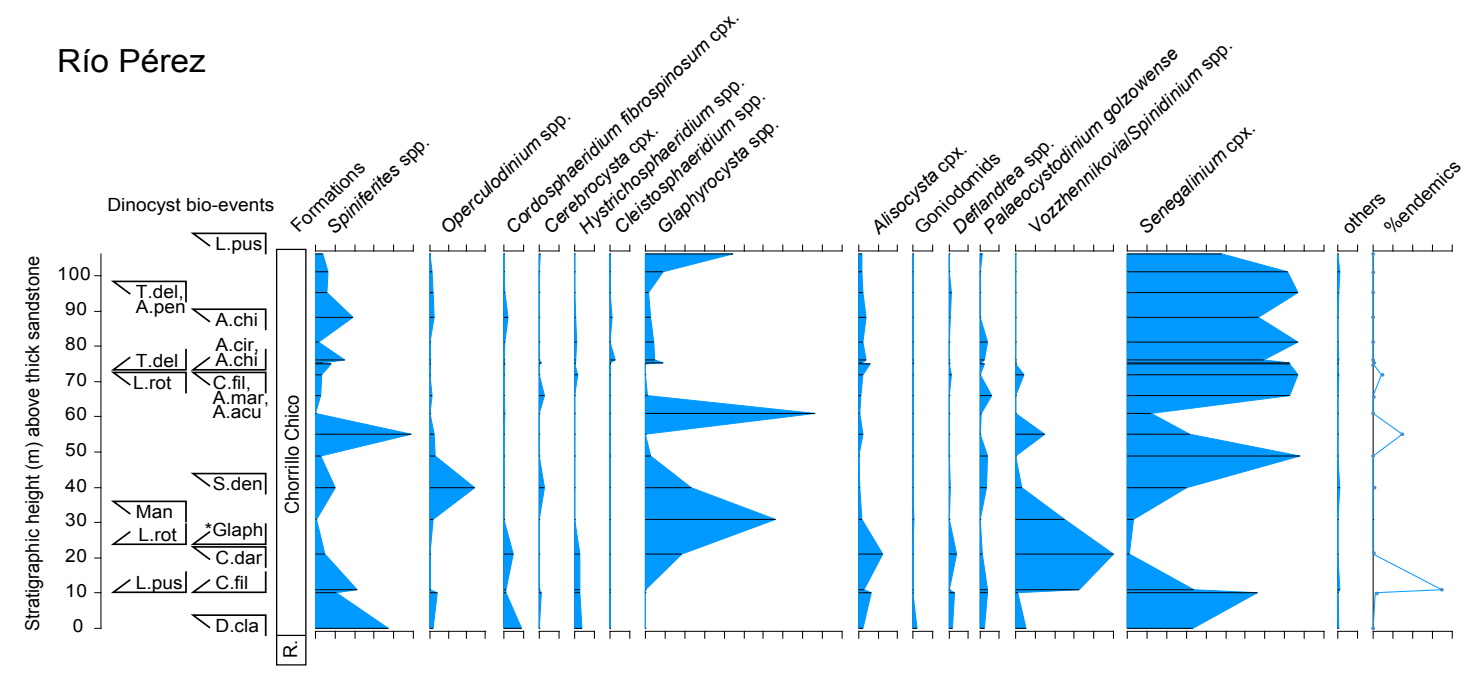

FIG. 4. Results from the Río Pérez section. Dinoflagellate cyst bioevents: L.pus: Leptodinium pustulatum, D.cla: Dinopterygium cladoides, C.fil: Cassidium filosum, C.dar: Cerodinium dartmooori, Man: Manumiella spp., *Glaph: acme of Glaphyrocysta spp., L.rot: Lejeunecysta rotunda, S.den: Spinidinium densispinatum, A.acu: Alterbidinium acutulum, A.mar: Alisocysta margarita, A.cir: Alisocysta circumtabulata, A.chi: Alisocysta chilensis, T.del: Thalassiphora delicata, A.pen: Alterbidinium pentaradiatum. Dinoflagellate cyst events that are above or below the presented section define minimum or maximum ages for the section, respectively. Formations (R.: Rocallosa Formation). Dinoflagellate cyst assemblages (in relative abundances of the in situ dinoflagellate cyst assemblage) plotted as eco-groups (following Sluijs et al., 2005) from the Río Pérez section (horizontal axis tick unit is 10\%). Dinoflagellate cyst eco-groups are ordered from distal to coastal gonyaulacoid cysts, and then peridinioid cysts. Also plotted are \% endemic dinoflagellate cysts. For raw counts see supplementary material. For which species are considered endemics see Methods.

formations (Supplement 1). Unfortunately, the formation boundaries could not be seen in the field, due to abundance of overgrowth and lack of exposed rocks. At this location, the Rocallosa Formation consists of thick, consolidated, reddish-brown medium-sandstones, intercalated with fine-grained siltstones with clay. The transition to Chorrillo Chico Formation is reflected by the disappearance of the sandstone layers; the sediments grade into silt-sized, homogeneous shales. The Agua Fresca Formation was recognized in the field as a $2 \mathrm{~m}$ thick conglomerate, followed by $6 \mathrm{~m}$ of unexposed section, $6 \mathrm{~m}$ of dark grey shales and $2 \mathrm{~m}$ of green sands. Sediments of Tres Brazos Formation consist of dark brown shales, with abundant root mottling.

\subsubsection{Well SELK-65; Leña Dura Formation}

Well SELK-65 was drilled west of the Río Los Palos section (Fig. 1D), and sediments include part of the Leña Dura Formation. The sediments are finegrained siltstones, dark, but the cores are relatively intensely shattered (Fig. 6). We sampled Cores 1-15 at a resolution of $50 \mathrm{~cm}$. Cores 4-6 were missing.

\subsubsection{Río Los Palos; Loreto Formation}

The Río Los Palos valley reaches the Otway Sound (Fig. 1D) at Estancia San Carlos. The valley allows sampling the upper Eocene Loreto Formation. Outcrops are well-accessible on either side of the valley, and consist of extensive marine and fluvial facies, that included finegrained heterolithic sediments at the base. Leaf debris is abundant throughout the section, but one $5 \mathrm{~m}$ thick finer-grained sediment unit contained marine macrofossil remains (Fig. 7). Paleo-current orientation based on sediment structures is consistently from the east (NE to $\mathrm{SE}$ ). We sampled relatively fine grained sediments at several stratigraphically successive outcrops exposed along the river, up to approximately $3 \mathrm{~km}$ upstream from the Estancia.

\subsection{Brunswick Peninsula region: sections and samples}

\subsubsection{Well RGP-03; Tres Brazos Formation}

Well RGP-03 was drilled approximately $15 \mathrm{~km}$ southwest of the Pecket Mine (Fig. 1C), and recovered 


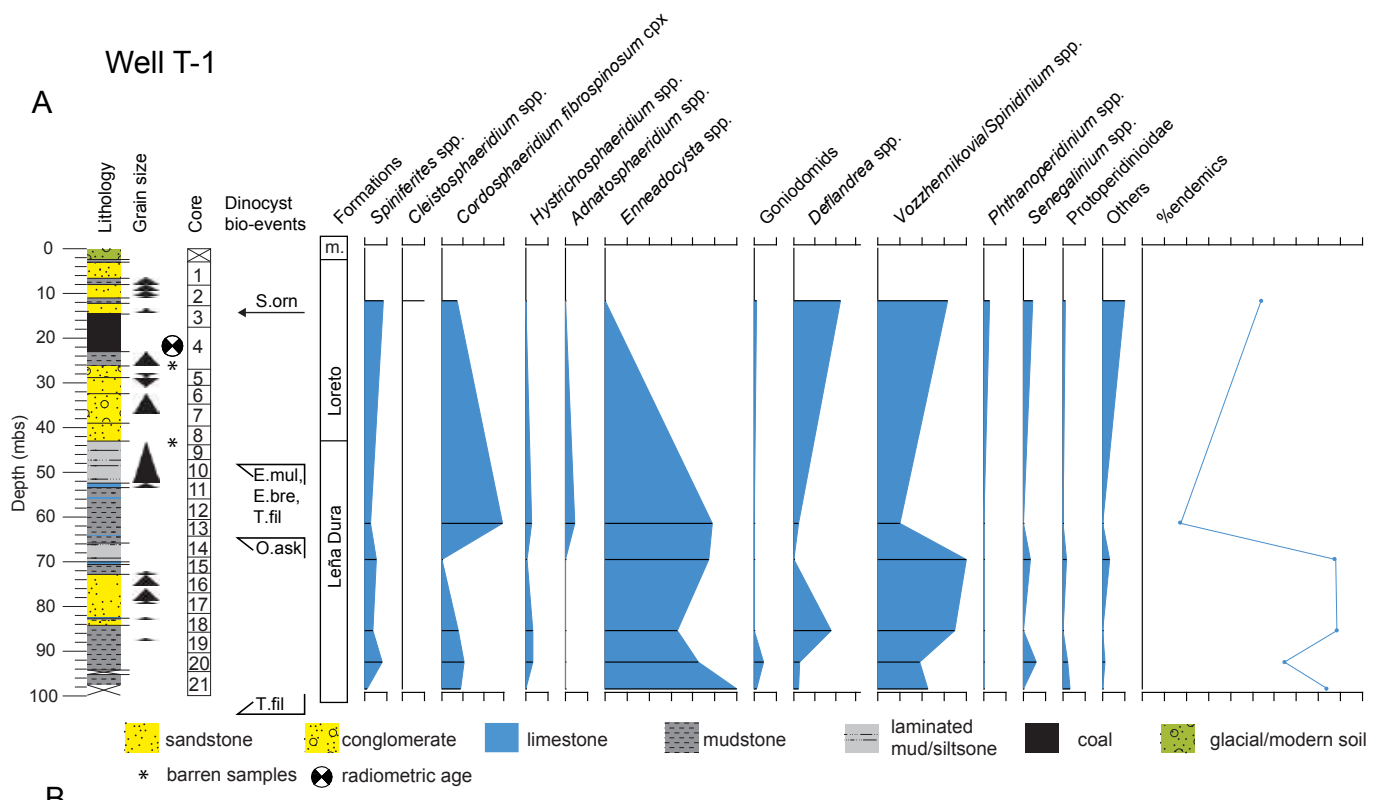

B

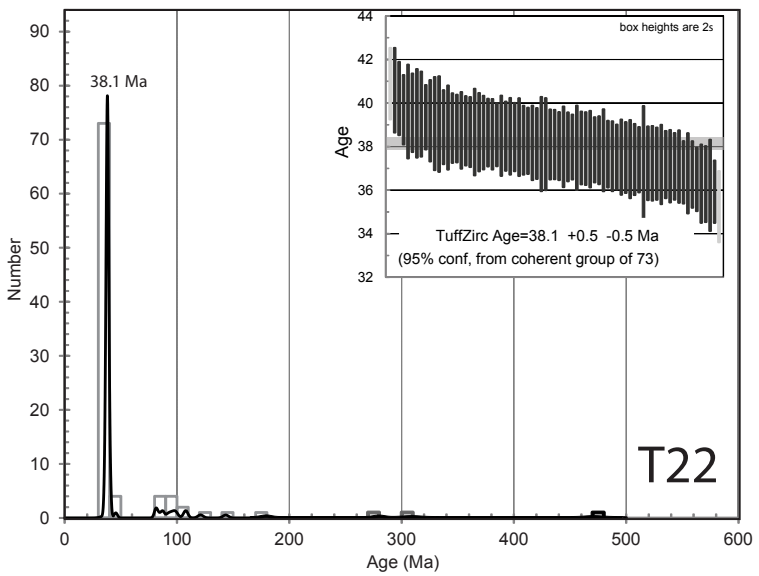

FIG. 5. A. Results from well T-1. Core description and legend, core sections. Black triangles indicate fining upward sequences. Dinoflagellate cyst bioevents: T.fil: Turbiosphaera filosa, O.ask: Octodinium askiniae, E.mul: Enneadocysta multicornuta, E.bre: Enneadocysta brevistila, S.orn: Stoveracysta ornata. Formations (m.: modern soil). Dinoflagellate cyst events that are above or below the presented section define minimum or maximum ages for the section, respectively. Dinoflagellate cyst eco-groups and relative abundance of endemic dinoflagellate cysts (horizontal axis tick unit is $10 \%$ ). For core location see figure 1. Dinoflagellate cyst eco-groups are ordered from distal to coastal gonyaulacoid cysts, and then peridinioid cysts. B. Results of zircon U-Pb ages from well T-22. The stratigraphic location of the sample taken for zircon analyses in T-22 could be well-correlated to the nearby T-1 well and is indicates at $\sim 21 \mathrm{~m}$. Seventy-four out of 93 zircons were grouped in a major peak at $38.1 \pm 0.5 \mathrm{Ma}$, with a unimodal distribution.

part of the lower/middle Eocene Tres Brazos Formation. Sediments consist of consolidated, lightcolored alternation of massive sandstones and wavy laminated heterolithic units (Fig. 8). Sandstone units become coarser up-section. We sampled Cores 2-25 at a resolution of $80 \mathrm{~cm}$. Core 18 features a $30 \mathrm{~cm}$ thick oyster bed.

\subsubsection{Pecket Mine; Loreto Formation}

The open mine pit Pecket on the west coast of northern Brunswick Peninsula (Fig. 1C) reaches a depth of $120 \mathrm{~m}$ into the subsurface (Fig. 9). The section consists of an alternation of siltstone shales, incisive, fining upwards sandstone channels, heterolithic units and coal deposits. Fossil leaf 


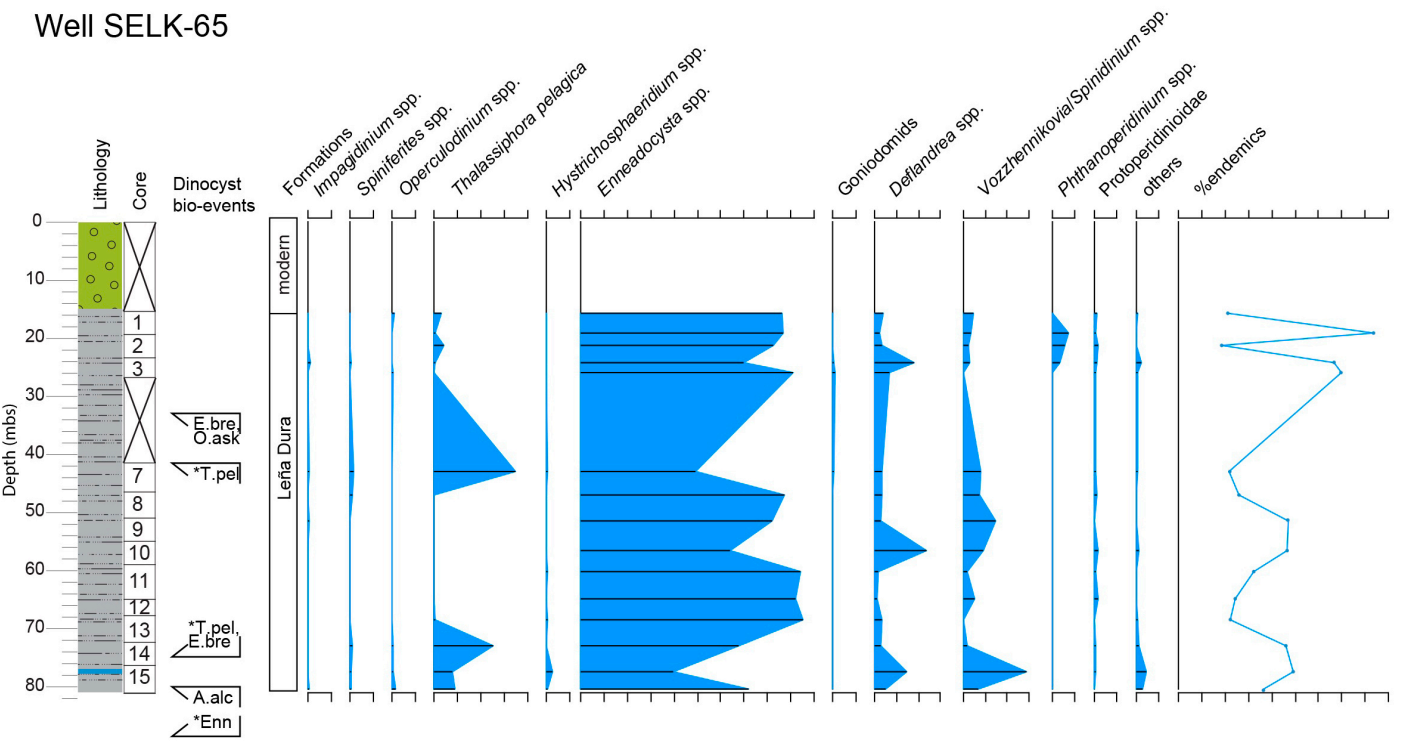

FIG. 6. Results from well SELK-65. Core description (for legend see Fig. 5), core sections. Dinoflagellate cyst bioevents: *Enn: acme Enneadocysta spp., A.alc: Achomosphaera alcicornu, *T.pel: acme Thalassiphora pelagica, O.ask: Octodinium askiniae, E.bre: Enneadocysta brevistila. Dinoflagellate cyst events that are above or below the presented section define minimum or maximum ages for the section, respectively. Dinoflagellate cyst eco-groups and relative abundance of endemic dinoflagellate cysts (horizontal axis tick unit is $10 \%$ ). For core location see figure 1. Dinoflagellate cyst eco-groups are ordered from distal to coastal gonyaulacoid cysts, and then peridinioid cysts.

debris and bioturbation are common throughout the section, which covers part of the Loreto Formation. One $\sim 10 \mathrm{~kg}$ sample was taken from the base of the section for $\mathrm{U} / \mathrm{Pb}$ radiometric dating of zircons from a white volcanic ash located inside coals (Tonstein; Fig. 9).

\section{Methods}

\subsection{Palynology}

The palynological processing techniques applied to a selection of 104 samples from the various locations (Table 1) were previously described by Bijl et al. (2013a). Briefly, this involves freeze-drying, crushing of the sediment to millimeter-size chips and spiking of the sample with a known amount $(9,666$ specimens +/- error per sample) of Lycopodium clavatum spores, to enable quantitative assessment of dinoflagellate cysts. Chemical treatment included two rounds of (38\%) HF digestion, followed by $(30 \%) \mathrm{HCl}$ rinsing steps to eliminate the fluoride gels that emerged from silicate digestion. Kerogen residues we subsequently sieved, with help of an ultrasonic bath to break up clumps of amorphous organic matter. The 250 to $10 \mu \mathrm{m}$ size fraction was mounted on microscope slides for analyses of palynomorphs. The minimum count completed was 200 specimens where possible: for some samples, yields were too low to achieve this. We discarded samples with counts below 30. Taxonomy follows that cited in Williams et al. (2017). Dinoflagellate cyst counting was performed under light microscopy with 400x magnification. Palynological residues and slides were stored in the collection of the Marine Palynology and Paleoceanography group, Laboratory of Palaeobotany and Palynology, Department of Earth Sciences, Utrecht University.

\subsection{Stratigraphy}

Assessment of the calibration of dinoflagellate cyst bioevents follows that in the available literature. Helby et al. (1987) calibrated dinoflagellate cyst bioevents from Australia to Cretaceous ammonite zonations. Mao and Mohr (1992) recognized dinoflagellate cyst bioevents in sediments from Maud Rise, which were independently dated using nannofossil stratigraphy. 


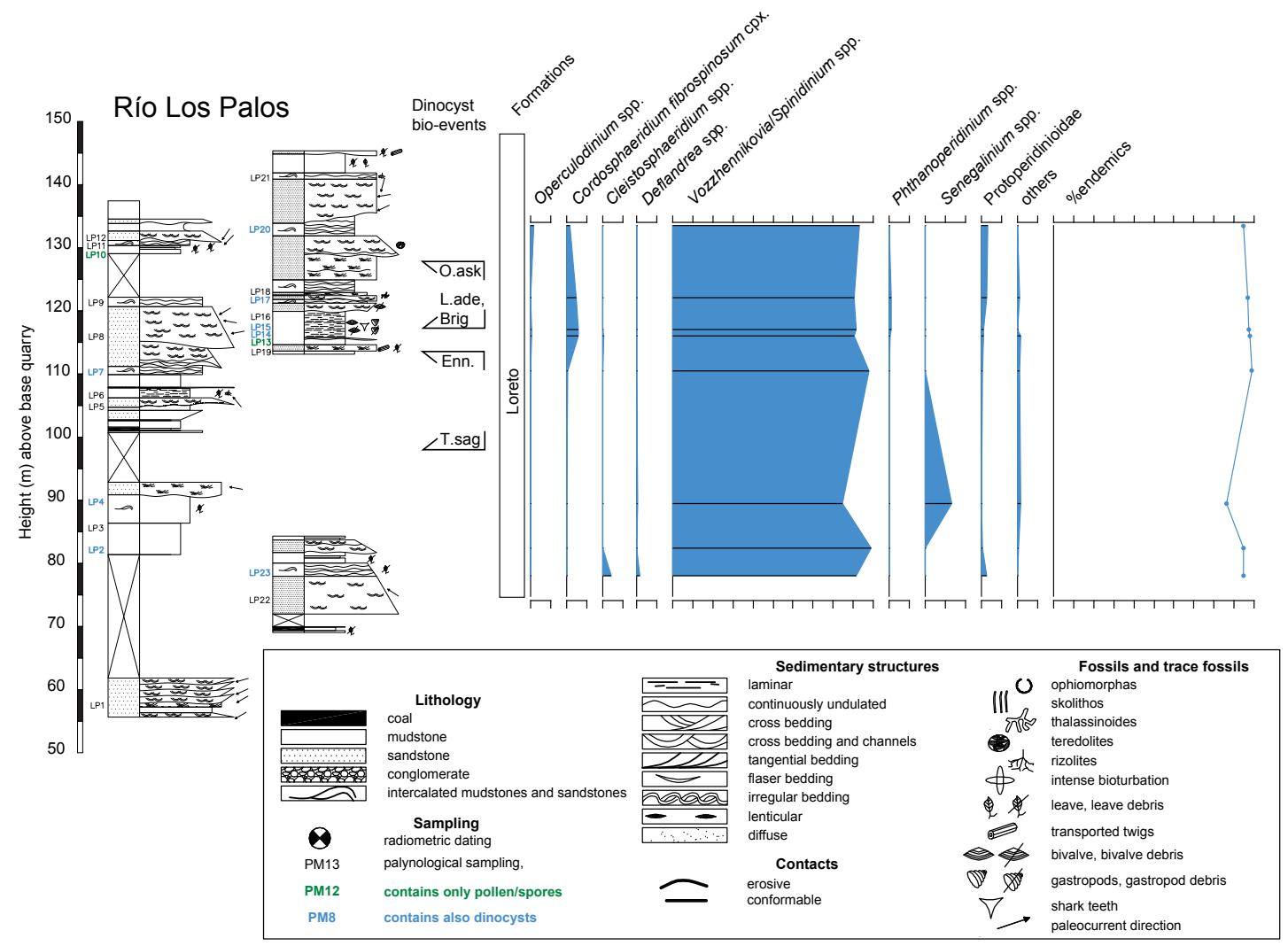

FIG. 7. Results from Río Los Palos. Lithologic log of outcrops along the river valley (see section 2.4.3), sample positions. Dinoflagellate cyst bioevents: T.sag: Turbiosphaera sagena, Enn.: Enneadocysta spp., Brig.: Brigantedinium spp., L.ade: Lejeunecysta adeliense, O.ask: Octodinium askiniae. Dinoflagellate cyst eco-groups and relative abundance of endemic dinoflagellate cysts (horizontal axis tick unit is $10 \%$ ). For location of the outcrops see figure 1. Dinoflagellate cyst eco-groups are ordered from distal to coastal gonyaulacoid cysts, and then peridinioid cysts.

Frieling et al. (2018) identified dinoflagellate cyst bioevents from the Paleocene-Eocene Boundary interval in South Australia, calibrated using stable carbon isotope stratigraphy. Sluijs et al. (2003) calibrated dinoflagellate cyst bioevents from late Eocene-Oligocene successions around Tasmania to the available magnetostratigraphy, which in turn was interpreted using diatom, nannofossil and foraminifer biostratigraphy. This study was later expanded, updated and refined by Houben et al. (2019). Bijl et al. (2013b) updated and expanded the work by Brinkhuis et al. (2003b) on dinoflagellate cyst bioevents from MaastrichtianEocene sediments from offshore Tasmania. Using additional independent constraints from isotope stratigraphy and recalibrating the ages to the GTS2012 time scale of Gradstein et al. (2012), Bijl et al. (2013b) provided a dinoflagellate cyst zonation scheme. This scheme could also be tied to Paleocene-Eocene zonations for New Zealand (Crouch and Brinkhuis, 2005; Crouch et al., 2014). We also compare our dinoflagellate cyst bioevents to those presented in zonations from Southern Argentina (González Estebenet et al., 2016), which consistently follow that of the southwest Pacific Ocean, and benefit from radiometric dating. We plot the known stratigraphic ranges of dinoflagellate cyst species in figure 2 and provide the ages of the bioevents in table 3 .

\subsection{Assessing dinoflagellate cyst endemism}

Assignment of biogeographic affinities of dinoflagellate cysts follow that in Bijl et al. (2011), with modifications proposed by Sluijs and Brinkhuis (2009), Frieling and Sluijs (2018) and 


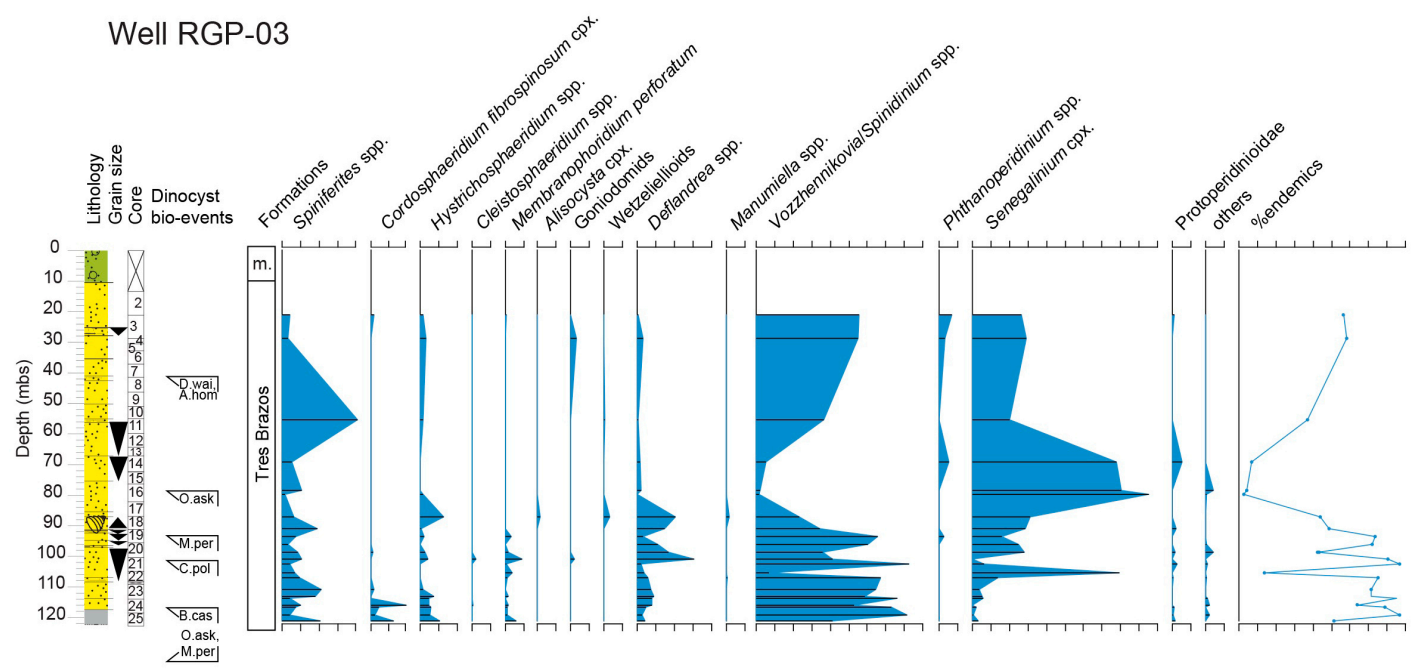

FIG. 8. Results from well RGP-03. Core description (for legend see Fig. 5), cores. Dinoflagellate cyst bioevents: B.cas: Batiacasphaera cassicula, C.pol: Cleistosphaeridium polypetellum, M.per: Membranophoridium perforatum, O.ask: Octodinium askiniae, D.wai: Dracodinium waipawaense, A.hom: Apectodinium homomorphum. Dinoflagellate cyst events that are above or below the presented section define minimum or maximum ages for the section, respectively. Lithology (m.: modern). Dinoflagellate cyst eco-groups and relative abundance of endemic dinoflagellate cysts. Samples with counts below 30 were discarded from the assemblage plot. For core location see figure 1. Dinoflagellate cyst eco-groups are ordered from distal to coastal gonyaulacoid cysts, and then peridinioid cysts (horizontal axis tick unit is 10\%).

Cramwinckel et al. (2019) on the non-endemic nature of Phthanoperidinium stockmansii and Hystrichosphaeridium truswelliae. The endemic dinoflagellate cysts are those that are biogeographically restricted to the Southern Ocean or are bi-polar. The other taxa are hence cosmopolitan (e.g., Spiniferites, Glaphyrocysta, Cordosphaeridium, Cleistosphaeridium, Senegalinium) but we might also encounter species with clear affinities to warmer temperatures and lower latitudes (e.g., the Wetzelielloids or Goniodomideae; Frieling et al., 2014; Frieling and Sluijs, 2018).

\subsection{Paleoceanographic interpretation dinoflagellate cyst assemblages}

Following earlier work (see e.g., Sluijs et al., 2005 for an overview) the dinoflagellate cyst assemblages are presented in eco-groups, according to their preferred niche on the continental shelf. This grouping allows qualitative detection of changes in paleoceanographic conditions: distance to shore, surface-water nutrient conditions, surface-water salinity and runoff and allows identification of transgressive sands. Recently, these qualitative ecologic affinities were semi-quantitatively constrained by Frieling and Sluijs (2018). Table 4 provides the ecologic affinities of dinoflagellate cyst eco-groups.

\subsection{U-Pb dating of detrital zircons}

Zircons in this study were analyzed for their U-Pb age at the Radiogenic Isotope and Geochronology Lab (RIGL) at Washington State University. We use the data reduction protocol described in detail by Chang et al. (2006), which we also briefly discuss here. Each analysis consists of a 30 second gas blank followed 30 seconds of ablation. Analyses were conducted using a New Wave $213 \mathrm{~nm}$ solid state (Nd:YAG) laser ablation system couple to a ThermoFinnigan Element2 ICPMS. Laser ablation parameters used for this study employed laser spot size diameters of $30 \mu \mathrm{m}$, with a repetition rate of $10 \mathrm{~Hz}$, and a few of $\sim 4-5 \mathrm{~J} / \mathrm{cm}^{2}$. For each analysis, the first $\sim 6$ seconds of data produced, as the sample signal reaches maximum signal intensity, are not considered. The next $\sim 30$ seconds of data are used to calculate $\mathrm{U}-\mathrm{Th}-\mathrm{Pb}$ isotope ratios by measuring the intensities at masses ${ }^{202} \mathrm{Hg},{ }^{204} \mathrm{~Pb}+\mathrm{Hg},{ }^{206} \mathrm{~Pb},{ }^{207} \mathrm{~Pb},{ }^{208} \mathrm{~Pb},{ }^{232} \mathrm{Th}$, ${ }^{235} \mathrm{U}$ and ${ }^{238} \mathrm{U}$ during $\sim 300$ sweeps through the mass 


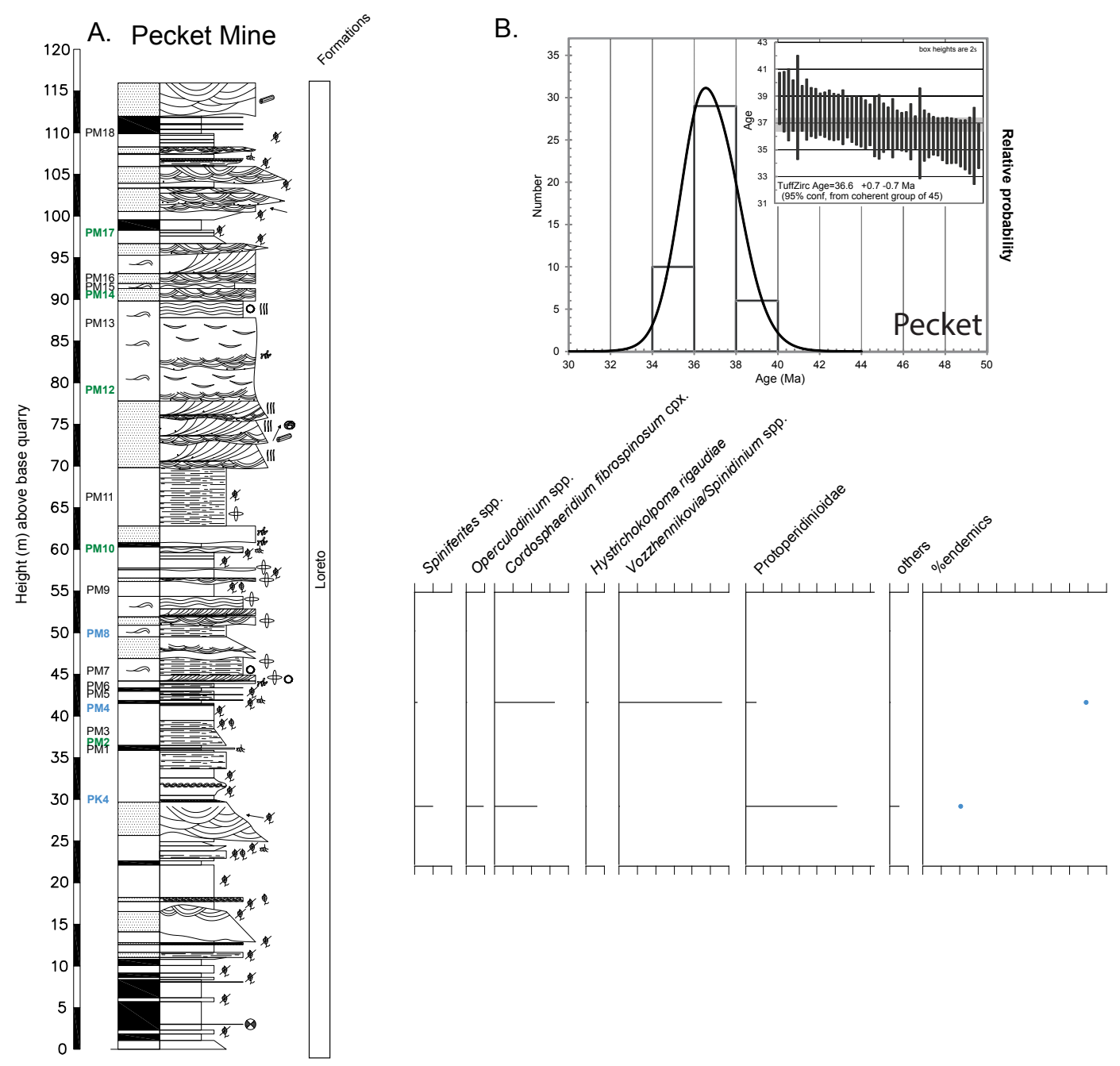

FIG. 9. A. Results from the Pecket Mine outcrop. Lithologic log (for legend see Fig. 7), sample positions and dinoflagellate cyst ecogroups and relative abundance of endemic dinoflagellate cysts. For core location see figure 1. Dinoflagellate cyst eco-groups are ordered from distal to coastal gonyaulacoid cysts, and then peridinioid cysts (horizontal axis tick unit is 10\%). B. Results of zircon $\mathrm{U}-\mathrm{Pb}$ radiometric dates, where 45 zircons were analyzed with a primary uni-modal distribution yield an age of 36.6 $\pm 0.7 \mathrm{Ma}$.

range. The mean count rate of each isotope during the 30 -second gas blank (300 sweeps) is subtracted from each sweep through the mass range collected during ablation (300 sweeps). Following gas blank (i.e., "background") correction, ${ }^{206} \mathrm{~Pb} /{ }^{238} \mathrm{U},{ }^{207} \mathrm{~Pb} /{ }^{235} \mathrm{U}$, and ${ }^{207} \mathrm{~Pb} /{ }^{206} \mathrm{~Pb}$ ratios are determined for each sweep for both samples and standards. Due to the well-known phenomenon of U-Pb elemental fractionation during laser ablation, which manifests as increasing U-Pb ratios with ablation depth (e.g., Jackson et al., 2004; Paton et al., 2010), we account for variable U-Pb fractionation, using the intercept method of Sylvester and Ghaderi (1997) for the U-Pb ratios. Conversely, the measured ${ }^{207} \mathrm{~Pb} /{ }^{206} \mathrm{~Pb}$ is determined using the arithmetic mean of all sweeps, as there is no observable fractionation of this ratio as ablation proceeds.

Analyses of unknown zircons and quality control zircons are interspersed with analyses of external calibration standards, typically with 7-10 unknowns bracketed by multiple analyses of two different zircon standards (Plešovice and FC-1). Plešovice ( $337 \mathrm{Ma}$; Sláma et al., 2008) was used to calibrate the ${ }^{206} \mathrm{~Pb} /{ }^{238} \mathrm{U}$ 
TABLE 3. DINOFLAGELLATE CYST BIOEVENTS AND ECOLOGIC AND BIOGEOGRAPHIC AFFINITY. $\left(^{*}\right)$

\begin{tabular}{|c|c|c|c|c|c|c|c|}
\hline Species & FAD & LAD & Source & Region & P or $G$ & Eco-group & Endemic? \\
\hline Achomosphaera alcicornu & 48.9 & - & Bijl et al., 2013b & Australia & G & Spiniferites cpx & No \\
\hline Achomosphaera crassipellis & 53.3 & 37.0 & Bijl et al., 2013b & Australia & G & Spiniferites cpx & No \\
\hline Adnatosphaeridium sp. & - & - & - & - & G & Adnatosphaeridium spp. & No \\
\hline Alisocysta circumtabulata & 67.5 & 54.0 & $\begin{array}{l}\text { Helby et al., 1987; } \\
\text { Bijl et al., 2013b }\end{array}$ & Australia & G & Alisocysta cpx & No \\
\hline Alisocysta margarita & 60.0 & 59.0 & Crouch et al., 2014 & New Zealand & G & Alisocysta $\mathrm{cpx}$ & No \\
\hline Alterbidinium acutulum & 70.6 & 55.5 & $\begin{array}{l}\text { Mao and Mohr, 1995; } \\
\text { Raine et al., } 1997\end{array}$ & $\begin{array}{l}\text { Kerguelen } \\
\text { Plateau; } \\
\text { Australia }\end{array}$ & $\mathrm{P}$ & Senegalinium $\mathrm{cpx}$ & No \\
\hline $\begin{array}{l}\text { Alterbidinium } \\
\text { pentaradiatum }\end{array}$ & 64.4 & 61.9 & Crouch et al., 2014 & New Zealand & $\mathrm{P}$ & Senegalinium cpx & No \\
\hline Amphidiadema denticulata & 85 & 74 & $\begin{array}{l}\text { Helby et al., 1987; } \\
\text { Mohr and Mao, } 1997\end{array}$ & $\begin{array}{l}\text { Australia; } \\
\text { Kerguelen } \\
\text { Plateau }\end{array}$ & $\mathrm{P}$ & Senegalinium cpx & No \\
\hline $\begin{array}{l}\text { Apectodinium } \\
\text { homomorphum }\end{array}$ & 58.8 & 48.3 & Bijl et al., 2013b & Australia & $\mathrm{P}$ & Wetzeliellioidae & No \\
\hline Areoligera $\mathrm{sp.}$ & - & - & - & - & G & Glaphyrocysta $\mathrm{cpx}$ & No \\
\hline Batiacasphaera cassicula & 54.0 & 48.3 & Bijl et al., 2013b & Australia & G & Alisocysta $\mathrm{cpx}$ & No \\
\hline Brigantedinium simplex & 40.0 & 0.0 & Bijl et al., 2013b & Australia & $\mathrm{P}$ & Protoperidinioidae & No \\
\hline Cassidium filosum & 59.0 & 57.3 & Bijl et al., 2013b & Australia & G & Alisocysta $\mathrm{cpx}$ & No \\
\hline Cassidium fragile & 65.7 & 34.4 & $\begin{array}{l}\text { Raine et al., 1997; } \\
\text { van Mourik et al., } 2001\end{array}$ & $\begin{array}{l}\text { Australia; } \\
\text { N atlantic }\end{array}$ & G & Alisocysta $\mathrm{cpx}$ & No \\
\hline Cerebrocysta bartonensis & 53.7 & 38.6 & $\begin{array}{l}\text { Brown and Downie, 1984; } \\
\text { Powell, } 1992\end{array}$ & North Sea & G & Cerebrocysta $\mathrm{cpx}$ & No \\
\hline Cerodinium dartmoorium & - & 55.4 & Bujak and Mudge, 1994 & North Sea & $\mathrm{P}$ & Deflandrea $\mathrm{cpx}$ & No \\
\hline $\begin{array}{l}\text { Cerodinium sp. } \\
\text { A small sensu } 1172\end{array}$ & 61.9 & 59.9 & Bijl, personal observation, 2020 & Australia & $\mathrm{P}$ & Deflandrea cpx & No \\
\hline Cerodinium striatum & 67.0 & 56.8 & $\begin{array}{l}\text { Brinkhuis et al., 2003b; } \\
\text { Bijl, personal observation, } 2020\end{array}$ & Australia & $\mathrm{P}$ & Deflandrea $\mathrm{cpx}$ & No \\
\hline Circulodinium distinctum & - & - & - & - & G & Glaphyrocysta $\mathrm{cpx}$ & No \\
\hline $\begin{array}{l}\text { Cleistosphaeridium } \\
\text { diversispinosum }\end{array}$ & 49.3 & 37.8 & Bijl et al., 2013b & Australia & G & Cleistosphaeridium spp. & No \\
\hline $\begin{array}{l}\text { Cleistosphaeridium } \\
\text { placacanthum }\end{array}$ & 53.3 & 51.4 & Bijl et al., 2013b & Australia & G & Cleistosphaeridium spp. & No \\
\hline $\begin{array}{l}\text { Cleistosphaeridium } \\
\text { polypetellum }\end{array}$ & 54.0 & 51.6 & Bijl et al., 2013b & Australia & G & Cleistosphaeridium spp. & No \\
\hline $\begin{array}{l}\text { Cordosphaeridium } \\
\text { fibrospinosum }\end{array}$ & 70.5 & 31.6 & Williams et al., 1993 & North Atlantic & G & $\begin{array}{l}\text { Cordosphaeridium } \\
\text { fibrospinosum } \mathrm{cpx}\end{array}$ & No \\
\hline Dapsilidinium pastielsii & 37.1 & 37.4 & van Mourik et al., 2005 & $\begin{array}{l}\text { Eastcoast } \\
\text { USA }\end{array}$ & G & Diphyes cpx & No \\
\hline Deflandrea antarctica & 57.7 & - & Bijl et al., 2013b & Australia & $\mathrm{P}$ & Deflandrea $\mathrm{cpx}$ & Yes \\
\hline Deflandrea foveolata & 62.4 & 58.7 & Crouch et al., 2014 & New Zealand & $\mathrm{P}$ & Deflandrea $\mathrm{cpx}$ & No \\
\hline Deflandrea oebisfeldensis & 61.5 & 50.7 & $\begin{array}{l}\text { Raine et al., 1997; } \\
\text { Powell et al., } 1992\end{array}$ & $\begin{array}{l}\text { Southern } \\
\text { Hemisphere; } \\
\text { North Sea }\end{array}$ & $\mathrm{P}$ & Deflandrea cрх & No \\
\hline Dinopterygium cladoides & - & 66.4 & Brinkhuis et al., 2003b & Australia & G & Goniodomidae & No \\
\hline Diphyes colligerum & 61.5 & 31.5 & $\begin{array}{l}\text { Bijl et al., 2013b; } \\
\text { Brinkhuis and Biffi, } 1993\end{array}$ & $\begin{array}{l}\text { Australia; } \\
\text { North Sea }\end{array}$ & G & Diphyes cpx & No \\
\hline Dracodinium waipawaense & 54.0 & 50.0 & Bijl et al., 2013b & Australia & $\mathrm{P}$ & Wetzeliellioidae & No \\
\hline Eisenackia chilensis & 61.5 & 59.2 & Bijl et al., 2013b & Australia & G & Alisocysta cpx & No \\
\hline
\end{tabular}


Table 3 continued.

\begin{tabular}{|c|c|c|c|c|c|c|c|}
\hline Species & FAD & LAD & Source & Region & P or $\mathrm{G}$ & Eco-group & Endemic? \\
\hline Eisenackia reticulata & 68.8 & 59.0 & $\begin{array}{l}\text { Brinkhuis et al., 2003b; } \\
\text { Crouch et al., } 2014\end{array}$ & $\begin{array}{l}\text { Australia; } \\
\text { New Zealand }\end{array}$ & G & Alisocysta $\mathrm{cpx}$ & No \\
\hline Elytrocysta brevis & 65 & 53.9 & $\begin{array}{l}\text { Bijl, personal observation, 2020; } \\
\text { Brown and Downie, } 1984\end{array}$ & $\begin{array}{l}\mathrm{C} \text { and } \mathrm{N} \\
\text { atlantic }\end{array}$ & G & Elytrocysta cpx & No \\
\hline Enneadocysta brevistila & - & - & - & - & G & Enneadocysta spp. & Yes \\
\hline Enneadocysta dictyostila & 47.9 & 33.2 & Bijl et al., 2013b & Australia & G & Enneadocysta spp. & Yes \\
\hline Enneadocysta multicornuta & 47.3 & 35.3 & Bijl et al., 2013b & Australia & G & Enneadocysta spp. & No \\
\hline Enneadocysta pectiniformis & 42.8 & 26.9 & $\begin{array}{l}\text { Head and Norris, 1989; } \\
\text { Egger et al., } 2016\end{array}$ & N Atlantic & G & Enneadocysta spp. & No \\
\hline Eocladopyxis peniculata & 47.3 & 33.9 & Bijl et al., 2013b & Australia & G & Goniodomidae & Yes \\
\hline Fibrocysta bipolaris & 59.7 & - & Masure et al., 1998 & $\mathrm{C}$ atlantic & G & $\begin{array}{l}\text { Cordosphaeridium } \\
\text { fibrospinosum cpx }\end{array}$ & No \\
\hline Florentinia mantelli & 131.4 & 65.7 & $\begin{array}{l}\text { Williams et al., 1993; } \\
\text { Eshet et al., } 1992\end{array}$ & $\begin{array}{l}\text { N Atlantic; } \\
\text { Israel }\end{array}$ & G & Diphyes cpx & No \\
\hline Glaphyrocysta delicata & 59.1 & 45.7 & Bijl et al., 2013b & Australia & G & Glaphyrocysta cpx & No \\
\hline Glaphyrocysta retiintexta & 54.8 & 49.3 & Bijl et al., 2013b & Australia & G & Glaphyrocysta $\mathrm{cpx}$ & No \\
\hline Glaphyrocysta semitecta & 42.3 & 32.6 & $\begin{array}{l}\text { Firth, 1996; } \\
\text { Pross et al., } 2012\end{array}$ & $\begin{array}{l}\text { N Atlantic; } \\
\text { Italy }\end{array}$ & G & Glaphyrocysta cpx & No \\
\hline Heteraulacacysta porosa & 43.9 & 34.4 & $\begin{array}{l}\text { Gradstein et al., 1992; } \\
\text { Head and Norris, } 1989\end{array}$ & North Sea & G & Goniodomidae & No \\
\hline Homotryblium tasmaniense & 53.2 & 43.4 & Bijl et al., 2013b & Australia & G & Goniodomidae & No \\
\hline $\begin{array}{l}\text { Hystrichokolpoma } \\
\text { rigaudiae }\end{array}$ & 56.8 & 19.0 & Crouch et al., 2014 & New Zealand & G & Diphyes cpx & No \\
\hline $\begin{array}{l}\text { Hystrichosphaeridium } \\
\text { truswelliae }\end{array}$ & 59.1 & 38.3 & Bijl et al., 2013b & Australia & G & Hystrichosphaeridium spp. & No \\
\hline $\begin{array}{l}\text { Hystrichosphaeridium } \\
\text { tubiferum }\end{array}$ & 59.0 & 38.0 & Bijl et al., 2013b & Australia & G & Hystrichosphaeridium spp. & No \\
\hline $\begin{array}{l}\text { Hystrichostrogylon } \\
\text { membraniphorum }\end{array}$ & 49.3 & 38.3 & Bijl et al., 2013b & Australia & G & Spiniferites cpx & No \\
\hline Impagidinium dispertitum & - & - & - & - & G & Impagidinium spp. & No \\
\hline Impagidinium maculatum & 57.1 & 33.7 & Raine et al., 1997 & Australia & G & Impagidinium spp. & No \\
\hline Impagidinium victorianum & 54.3 & 37.8 & Bijl et al., 2013b & Australia & G & Impagidinium spp. & No \\
\hline Isabelidinium bakeri & 76.8 & 71.7 & $\begin{array}{l}\text { Mao and Mohr, 1992; } \\
\text { Mohr and Mao, } 1997\end{array}$ & $\begin{array}{l}\text { Kerguelen } \\
\text { Plateau }\end{array}$ & $\mathrm{P}$ & Senegalinium $\mathrm{cpx}$ & No \\
\hline Isabellidinium cretaceum & 85.2 & 71.7 & Raine et al., 1997 & Australia & $\mathrm{P}$ & Senegalinium $\mathrm{cpx}$ & No \\
\hline Kenleyia sp. & - & - & - & - & G & $\begin{array}{l}\text { Cordosphaeridium } \\
\text { fibrospinosum } \mathrm{cpx}\end{array}$ & No \\
\hline Lejeunecysta adeliense & 33.7 & 32.6 & Bijl et al., 2018 & Antarctica & $\mathrm{P}$ & Protoperidinioidae & No \\
\hline Lejeunecysta hyalina & 65.7 & 14.9 & $\begin{array}{l}\text { Eshet et al., 1992; } \\
\text { Zegarra and Helenes, } 2011\end{array}$ & $\begin{array}{l}\text { Egypt; C } \\
\text { America }\end{array}$ & $\mathrm{P}$ & Protoperidinioidae & No \\
\hline $\begin{array}{l}\text { Lejeunecysta rotunda } \\
\text { (sensu } 1172)\end{array}$ & 60.7 & 62.8 & Bijl, personal observation, 2020 & Australia & $\mathrm{P}$ & Protoperidinioidae & No \\
\hline Leptodinium pustulatum & 61.0 & 56.5 & Crouch et al., 2014 & New Zealand & G & Cerebrocysta $\mathrm{cpx}$ & No \\
\hline $\begin{array}{l}\text { Lingulodinium } \\
\text { machaerophorum }\end{array}$ & 58.3 & 0.0 & Bijl et al., 2013b & Australia & G & Goniodomidae & No \\
\hline Manumiella rotunda & 59.1 & 53.2 & $\begin{array}{l}\text { Crouch et al., 2014; } \\
\text { Bijl et al., 2013b }\end{array}$ & $\begin{array}{l}\text { New Zealand; } \\
\text { Australia }\end{array}$ & $\mathrm{P}$ & Deflandrea cрх & No \\
\hline Manumiella seelandica & - & 66.0 & Bowman et al., 2012 & Antarctica & $\mathrm{P}$ & Deflandrea cpx & No \\
\hline Manumiella? small & - & - & - & - & $\mathrm{P}$ & Deflandrea $\mathrm{cpx}$ & No \\
\hline
\end{tabular}


Table 3 continued.

\begin{tabular}{|c|c|c|c|c|c|c|c|}
\hline Species & FAD & LAD & Source & Region & P or $\mathbf{G}$ & Eco-group & Endemic? \\
\hline $\begin{array}{l}\text { Membranophoridium } \\
\text { perforatum }\end{array}$ & 54.0 & 45.0 & Bijl et al., 2013b & Australia & G & $\begin{array}{l}\text { Membranophoridium } \\
\text { perforatum }\end{array}$ & Yes \\
\hline Microdinium sp. & - & - & - & - & G & Elytrocysta $\mathrm{cpx}$ & No \\
\hline Muratodinium fimbriatum & 58.6 & 50.6 & Powell et al., 1992,1996 & North Sea & G & Glaphyrocysta cpx & No \\
\hline Nelsoniella aceras & 84.3 & 78.4 & Raine et al., 1997 & Australia & $\mathrm{P}$ & Deflandrea $\mathrm{cpx}$ & No \\
\hline Nematosphaeropsis sp. & 51.4 & - & Bijl et al., 2013b & Australia & G & Nematosphaeropsis spp. & No \\
\hline Octodinium askiniae & 52.2 & 34.5 & $\begin{array}{l}\text { Bijl et al., 2013b; } \\
\text { Houben et al., } 2019\end{array}$ & Australia & $\mathrm{P}$ & other & Yes \\
\hline Odontochitina costata & 100 & 69.9 & $\begin{array}{l}\text { Tocher and Jarvis, 1996; } \\
\text { Costa and Davey, } 1992\end{array}$ & $\begin{array}{l}\text { Europe; } \\
\text { North Sea }\end{array}$ & G & Glaphyrocysta cpx & No \\
\hline Odontochitina porifera & 89.9 & 70.1 & $\begin{array}{l}\text { Williams et al., 1993; } \\
\text { Mao and Mohr, } 1992\end{array}$ & $\begin{array}{l}\text { N Atlantic; } \\
\text { Kerguelen } \\
\text { Plateau }\end{array}$ & G & Glaphyrocysta cpx & No \\
\hline Oligosphaeridium complex & 137.7 & 48.8 & Williams et al., 1993 & N Atlantic & G & other & No \\
\hline $\begin{array}{l}\text { Operculodinium large } \\
\text { sensu } 1172\end{array}$ & 68.4 & 65.6 & $\begin{array}{l}\text { Brinkhuis et al., 2003b; } \\
\text { Bijl, personal observation, } 2020\end{array}$ & Australia & G & Operculodinium spp. & No \\
\hline $\begin{array}{l}\text { Palaeocystodinium } \\
\text { golzowense }\end{array}$ & 81.0 & 50.7 & $\begin{array}{l}\text { Raine et al., 1997; } \\
\text { Bijl et al., 2013b }\end{array}$ & Australia & $\mathrm{P}$ & Palaeocystodinium spp. & No \\
\hline $\begin{array}{l}\text { Palaeohystrichophora } \\
\text { infusorioides }\end{array}$ & 103 & 71.7 & Helby et al., 1987 & Australia & $\mathrm{P}$ & Senegalinium cpx & No \\
\hline $\begin{array}{l}\text { Phthanoperidinium } \\
\text { stockmansii }\end{array}$ & 57.7 & 37.8 & Bijl et al., 2013b & Australia & $\mathrm{P}$ & Phthanoperidinium spp. & No \\
\hline Protoperidinioideae & - & - & - & - & $\mathrm{P}$ & Protoperidinioids & No \\
\hline Pyxidinopsis waipawaense & 59.1 & - & Bijl et al., 2013b & Australia & G & Cerebrocysta cpх & No \\
\hline Rhombodinium draco & 49.3 & 25.8 & $\begin{array}{l}\text { Bijl et al., 2013b; } \\
\text { Sliwinska et al., } 2012\end{array}$ & Denmark & $\mathrm{P}$ & Wetzeliellioidae & No \\
\hline Samlandia delicata & 55.5 & 49.0 & Bijl et al., 2013b & Australia & G & $\begin{array}{l}\text { Cordosphaeridium } \\
\text { fibrospinosum cpx }\end{array}$ & No \\
\hline Samlandia septata & 53.3 & 51.8 & Bijl et al., 2013b & Australia & G & $\begin{array}{l}\text { Cordosphaeridium } \\
\text { fibrospinosum cpx }\end{array}$ & No \\
\hline Selenopemphix brinkhuisii & $33.4^{*}$ & 30.6 & Bijl et al., 2018 & Antarctica & $\mathrm{P}$ & Protoperidinioidae & No \\
\hline Selenopemphix nephroides & 49.3 & - & Bijl et al., 2013b & Australia & $\mathrm{P}$ & Protoperidinioidae & No \\
\hline Senegalinium dilwynense & 65.7 & 54.0 & Raine et al., 1997 & Australia & $\mathrm{P}$ & Senegalinium cpx & No \\
\hline Spinidinium densispinatum & 65.7 & - & Raine et al., 1997 & Australia & $\mathrm{P}$ & Vozzhennikovia $\mathrm{cpx}$ & No \\
\hline Spinidinium macmurdoense & 56.8 & 30.0 & Bijl et al., 2013b & Australia & $\mathrm{P}$ & Vozzhennikovia $\mathrm{cpx}$ & Yes \\
\hline Spinidinium schellenbergii & 59.0 & - & Bijl et al., 2013b & Australia & $\mathrm{P}$ & Vozzhennikovia cpx & Yes \\
\hline Spiniferella cornuta & 59.7 & 56.2 & $\begin{array}{l}\text { Masure } \text { et al., 1998; } \\
\text { Awad and Oboh-Ikenobe, } 2016\end{array}$ & C Atlantic & G & Spiniferites $\mathrm{cpx}$ & No \\
\hline Stoveracysta ornata & 36.7 & 30.8 & Bijl et al., 2013b, 2018 & $\begin{array}{l}\text { Australia; } \\
\text { Antarctica }\end{array}$ & G & Alisocysta cpx & No \\
\hline Subtilisphaera perlucida & 135.5 & 72.7 & $\begin{array}{l}\text { Leereveld, 1997; } \\
\text { Mao and Mohr, } 1992\end{array}$ & $\begin{array}{l}\text { Spain; } \\
\text { Kerguelen } \\
\text { Plateau }\end{array}$ & $\mathrm{P}$ & Senegalinium $\mathrm{cpx}$ & No \\
\hline $\begin{array}{l}\text { Tanyosphaeridium } \\
\text { xanthiopyxides }\end{array}$ & 75.2 & 61.6 & $\begin{array}{l}\text { Mao and Mohr, 1992; } \\
\text { Masure et al., } 1998\end{array}$ & $\begin{array}{l}\text { Kerguelen } \\
\text { Plateau, } \\
\text { C Atlantic }\end{array}$ & G & other & No \\
\hline Tectatodinium pellitum & 65.4 & 0.0 & Powell, 1992 & North Sea & G & Cerebrocysta cpх & No \\
\hline Thalassiphora delicata & 60.7 & 56.9 & $\begin{array}{l}\text { Brinkhuis et al., 2003b; } \\
\text { Awad and Oboh-Ikenobe, } 2016\end{array}$ & $\begin{array}{l}\text { Australia; } \\
\text { C Atlantic }\end{array}$ & G & $\begin{array}{l}\text { Cordosphaeridium } \\
\text { fibrospinosum cpx }\end{array}$ & No \\
\hline
\end{tabular}


Table 3 continued.

\begin{tabular}{|c|c|c|c|c|c|c|c|}
\hline Species & FAD & LAD & Source & Region & P or $\mathbf{G}$ & Eco-group & Endemic? \\
\hline Thalassiphora pelagica & 56.0 & - & Bijl et al., 2013b & Australia & G & $\begin{array}{l}\text { Cordosphaeridium } \\
\text { fibrospinosum cpx }\end{array}$ & No \\
\hline $\begin{array}{l}\text { Trithyrodinium } \\
\text { vermiculatum }\end{array}$ & - & - & - & - & $\mathrm{P}$ & Senegalinium cpx & No \\
\hline Turbiosphaera filosa & 49.0 & 38.7 & Bijl et al., 2013b & Australia & G & $\begin{array}{l}\text { Cordosphaeridium } \\
\text { fibrospinosum } \mathrm{cpx}\end{array}$ & No \\
\hline Turbiosphaera sagena & 35.7 & 33.2 & Bijl et al., 2013b & Australia & G & $\begin{array}{l}\text { Cordosphaeridium } \\
\text { fibrospinosum cpx }\end{array}$ & No \\
\hline Vozzhennikovia angulata & 64.7 & 61.9 & Crouch et al., 2014 & New Zealand & $\mathrm{P}$ & Vozzhennikovia cpx & Yes \\
\hline Vozzhennikovia apertura & 59.0 & 34.1 & $\begin{array}{l}\text { Bijl et al., 2013b; } \\
\text { Houben et al., } 2019\end{array}$ & Australia & $\mathrm{P}$ & Vozzhennikovia $\mathrm{cpx}$ & Yes \\
\hline Vozzhennikovia roehliae & 53.0 & 33.2 & $\begin{array}{l}\text { Bijl et al., 2013b; } \\
\text { Sluijs et al., } 2009\end{array}$ & Australia & $\mathrm{P}$ & Vozzhennikovia cpx & Yes \\
\hline Vozzhennikovia stickleyae & 53.4 & 33.2 & Bijl et al., 2013b & Australia & $\mathrm{P}$ & Vozzhennikovia $\mathrm{cpx}$ & Yes \\
\hline
\end{tabular}

(*) Species name, first appearance data (FAD), last appearance data (LAD), source, region where these dinoflagellate cyst bioevents were calibrated (all (re-) calibrated to GTS2012 of Gradstein et al. (2012)) eco-group (see Table 4) and biogeographic affinity. N: North, C: Central, P: Peridinioid, G: Gonyaulacoid. This study suggests the FO might be older than the earliest Oligocene.

and ${ }^{207} \mathrm{~Pb} /{ }^{235} \mathrm{U}$ ages, and FC-1 (1099 Ma; Paces and Miller, 1993) was used for calibration of ${ }^{207} \mathrm{~Pb} /{ }^{206} \mathrm{~Pb}$, owing to much higher count rates for ${ }^{207} \mathrm{~Pb}(\sim 2-4$ times higher than Plešovice). The concentrations of $U, T h$, $\mathrm{Pb}$ are estimated by interspersing analyses of NIST610 glass which has well characterized concentrations of these elements. Final ages were determined using a standard-sample bracketing approach. U-Pb zircon crystallization ages were estimated and plotted using Isoplot 3.0 (Ludwig, 2003).

\section{Results}

Raw counts of dinoflagellate cysts and the detailed results of U-Pb dating of zircons can be found in Supplement 1. A list of dinoflagellate cyst species encountered is presented in table 3 and selected specimens are illustrated in Plates 1 and 2. We here describe the dinoflagellate cyst biostratigraphy and assemblages per studied section and integrate these with the $\mathrm{U}-\mathrm{Pb}$ dating results.

\subsection{Laguna Blanca región}

\subsubsection{Río Pérez; Chorillo Chico Formation}

All samples contain abundant, well-preserved, and diverse dinoflagellate cyst assemblages, as well as terrestrial palynomorphs. Stratigraphically important species include Alisocysta circumtabulata,
A. margarita, Eisenackia reticulata, E. chilensis, Alterbidinium pentaradiatum, Cassidium filosum, Cerodinium dartmoorium, C. striatum, and a previously undescribed Cerodinium taxon termed $C$. sp. A, which was also observed in Paleocene strata at ODP Site 1172 on the East Tasman Plateau (P.K. Bijl, personal observation, 2020). We also recorded Leptodinium pustulatum, abundant Glaphyrocysta, Isabelidinium bakeri, Lejeunecysta rotunda, Spinidinium densispinatum, Spiniferella cornuta, Tanyosphaeridium xanthiopyxides and Thalassiphora delicata (Fig. 4). The lowermost sample contains few specimens of the typical Maastrichtian (Brinkhuis et al., 1998, 2003b; Bowman et al., 2012) dinoflagellate cyst markers Manumiella seelandica and Dinopterygium cladoides. The presence of Leptodinim pustulatum throughout, along with the remaining assemblage, and the absence of typical earliest Danian stratigraphic markers such as Trithyrodinium evittii, Senoniasphaera inornata, and Palynodinium grallator, as well as absence of Palaeoperidinium pyrophorum suggests that most of the Danian is missing from the sequence. The presence of Alterbidinium pentaradiatum in the top of the outcrop is the only species in disagreement with this inference because this species occurs in the lower Danian of New Zealand (Crouch et al., 2014). A hiatus in the early Paleocene is consistent with observations regarding the outcrops at nearby Isla 
TABLE 4. ECOLOGIC AFFINITIES OF DINOFLAGELLATE CYST ECO-GROUPS.

\begin{tabular}{|c|c|c|}
\hline Eco-group & Ecologic affinity & Source \\
\hline Adnatosphaeridium & Mid-shelf & Sluijs et al., 2005 \\
\hline Alisocysta & Unknown; high terrestrial input? & Frieling and Sluijs, 2018 \\
\hline Cerebrocysta & Outer neritic? & Prebble et al., 2013 \\
\hline Cleistosphaeridium & Mid-shelf & Sluijs et al., 2005 \\
\hline $\begin{array}{l}\text { Cordosphaeridium } \\
\text { fibrospinosum }\end{array}$ & Mid-shelf & Sluijs et al., 2005 \\
\hline Deflandrea & High primary productivity, mid-shelf & Sluijs et al., 2005 \\
\hline Diphyes colligerum & Lagoonal & Sluijs et al., 2005 \\
\hline Elytrocysta & Mid-shelf? & Bijl, personal observation, 2020 \\
\hline Enneadocysta & Mid-shelf & Sluijs et al., 2005 \\
\hline Glaphyrocysta & Mid-shelf, transgressive, dynamic water & Sluijs et al., 2005 \\
\hline Goniodomids & $\begin{array}{l}\text { Warm, lagoonal, water column stratification, high } \\
\text { primary productivity }\end{array}$ & Sluijs et al., 2005; Frieling and Sluijs, 2018 \\
\hline Hystrichosphaeridium & Mid-shelf, cooler temperatures & Frieling and Sluijs, 2018 \\
\hline Impagidinium & Oceanic, offshore, oligotrophic & Sluijs et al., 2005 \\
\hline $\begin{array}{l}\text { Membranophoridium } \\
\text { perforatum }\end{array}$ & Mid-shelf & Sluijs et al., 2005 \\
\hline Nematosphaeropsis & Outer neritic & Prebble et al., 2013 \\
\hline Operculodinium & Outer neritic to mid-shelf & Sluijs et al., 2005; Prebble et al., 2013 \\
\hline Palaeocystodinium & Unknown & - \\
\hline Phthanoperidinium & Fresh-water input & Brinkhuis et al., 2006 \\
\hline Protoperidinium & High nutrients, prey species, high temperature? & Frieling and Sluijs, 2018 \\
\hline Senegalinium & $\begin{array}{l}\text { High primary productivity, fresh-water input, } \\
\text { cool temperatures }\end{array}$ & Frieling and Sluijs, 2018 \\
\hline Spiniferites & Cosmopolitan, outer neritic-open marine & Sluijs et al., 2005; Frieling and Sluijs, 2018 \\
\hline Thalassiphora pelagica & Water column stratification & Pross and Schmiedl, 2002 \\
\hline Vozzhennikovia & Cold water & Warnaar et al., 2009 \\
\hline Wetzeliellioids & Warm, normal marine, low terrestrial input & Sluijs et al., 2005; Frieling and Sluijs, 2018 \\
\hline
\end{tabular}

Riesco, where Selandian sediments of the Chorrillo Chico Formation directly and sharply overlie the Maastrichtian Rocallosa Formation (see section 4.2). Also, in the Calafate Formation, southern Patagonia Argentina, the K/Pg boundary is eroded and the uppermost part of the section was assigned to the latest Maastrichtian (Marenssi et al., 2004). In the upper part of the Río Pérez section, the presence of Eisenackia reticulata, FO of Glaphyrocysta delicata, Tanyosphaeridium spp. and Thalassiphora delicata suggests that the sampled section extends up to the Thanetian-Selandian boundary, or just into the Thanetian, although the Thanetian marker species Apectodinium homomorphum was not recorded (Fig. 2).

The assemblages are characterized by two successions from Senegalinium spp. via Spinidinium/ Vozzhennikovia to dominance of Glaphyrocysta spp., after which Senegalinium spp. remains dominant towards the top of the sampled section. The uppermost part of the section shows another increase in abundance of Glaphyrocysta spp. (Fig. 4).

\subsubsection{Fuentes; Fuentes Formation}

The two samples contain a modestly diverse dinoflagellate cyst assemblage (Supplement 1). 
Many species found in these samples have long stratigraphic ranges in the Cretaceous, therefore stratigraphic calibration of these samples mainly depends on the absence of some species which would make the samples any older or younger than the early Campanian. Of interest, we note the abundant occurrence of Trithyrodinium vermiculatum, a species described from the Santonian of southern Australia, but without a constrained stratigraphic range, and Amphidiadema denticulata. Odontochitina costata and $O$. porifera are also common. The presence of Nelsoniella aceras suggest that the top part of the Fuentes section is of early-mid Campanian age, particularly in absence of the typical upper Campanian-Maastrichtian species of Manumiella (Bowman et al., 2012).

\subsubsection{Wells T-1 and T-22; Leña Dura and Loreto formations}

Two out of the nine samples were barren of dinoflagellate cysts but did contain a diverse terrestrial palynomorph assemblage. The barren samples come from above the Leña Dura/Loreto boundary, and below the thick coal horizon. The samples from the Leña Dura Formation contain diverse and well-preserved dinoflagellate cysts. Species of stratigraphic importance include Enneadocysta dictyostila, E. brevistila, E. multicornuta, Eocladopyxis peniculata, Octodinium askiniae, and Turbiosphaera filosa (Fig. 5). This assemblage corresponds to the SPDZ11/SPDZ12 and the upper part of the zone RTF2 (González Estebenet et al., 2016), which an age $\sim 40 \pm 2 \mathrm{Ma}$. The single sample from the Loreto Formation from T-1 that yielded dinoflagellate cysts, lacks Enneadocysta multicornuta, E. brevistila and Turbiosphaera filosa, but contains Stoveracysta ornata, which tentatively suggests a younger age (36.7-32.1 Ma; Houben et al., 2019). U-Pb Zircon ages from a sandstone sample from the base of the Loreto Formation from Well T-22 shows a highly unimodal signature with $\sim 80 \%$ of the 93 analyzed grains falling in the $\sim 36$ to $\sim 40$ Ma age range (Fig. 5). Samples yield a TuffZirc ${ }^{206} \mathrm{~Pb} /{ }^{238} \mathrm{U}$ age of $38.1 \pm 0.5 \mathrm{Ma}(\mathrm{n}=73,2 \sigma)$. Minor subordinate Cretaceous peaks (81-121 Ma) are present. The age for the T-22 zircons is therefore broadly consistent with the dinoflagellate cyst ages. Dinoflagellate cyst assemblages are dominated by Enneadocysta spp. and the Spinidinium/Vozzhennikovia group, representing dominantly endemic taxa characteristic of mid-shelf conditions (Fig. 5).

\subsection{Isla Riesco región}

\subsubsection{North-coastal outcrops Isla Riesco; Rocallosa, Chorillo Chico, Agua Fresca, Tres Brazos formations}

The dinoflagellate cyst assemblages from this region confirm the tentatively suggested ages for the respective formations. From our samples, termed CAPO, from the Rocallosa Formation, we could not retrieve any dinoflagellate cysts. This testifies to the oxidative nature of the sedimentary regime, which might still have been marine in nature. The sediments from the directly overlying Chorrillo Chico Formation (CC) contain diverse marine dinoflagellate cyst assemblages including Leptodinium pustulatum, Apectodinium homomorphum and Eisenackia reticulata (Supplement 1), which indicate a mid-Selandian age (Table 3; Fig. 2). The two samples from the Agua Fresca Formation that we analyzed also yield a diverse dinoflagellate cyst assemblage with abundant $(>50 \%)$ Apectodinium homomorphum, a questionable specimen of Muratodinium fimbriatum and Hystrichokolpoma rigaudiae, tentatively placing these samples close to the Paleocene-Eocene boundary; although carbon isotope stratigraphy on a high-resolution sample set would be required to confirm the presence of the Paleocene-Eocene Thermal Maximum (Sluijs and Brinkhuis, 2009). The samples from Tres Brazos Formation are dominated by terrestrial organic matter and palynomorphs, the dinoflagellate cyst species present include Cleistosphaeridium polypetellum, which assigns the age of these samples to dinoflagellate cyst zone SPDZ3-5, mid-Ypresian (54-51.7 Ma; Bij1 et al., 2013b).

\subsubsection{Well SELK-65; Leña Dura Formation}

All samples contain abundant, diverse and well-preserved dinoflagellate cysts. Species of stratigraphic importance include Cleistosphaeridium diversispinosum, Dapsilidinium pastielsii, Enneadocysta brevistila, E. pectiniformis, Eocladopyxis peniculata, Hystrichosphaeridium tubiferum, Impagidinium victorianum, Octodinium askiniae and Vozzhennikovia roehliae (Fig. 6). This assemblage, plus the absence of Membranophoridium perforatum, Turbiosphaera filosa and Homotryblium tasmaniense allows us to assign this section to the upper SPDZ12-lower SPDZ13 of Bartonian age (Fig. 6). It also correlates to the upper part of zone RTF2, which according to Guerstein et al. (2014) 
includes the Middle Eocene Climatic Optimum, a global warming phase of about 500,000 years dated at $\sim 40 \mathrm{Ma}$ (Bohaty and Zachos, 2003; Bohaty et al., 2009; Cramwinckel et al., 2018). Unfortunately, typical marker species for the MECO, such as Dracodinium rhomboideum and Lophocysta spp., found elsewhere in association with the MECO, including the Southern Ocean (Bijl et al., 2013b), could not be positively identified. Assemblages are dominated by Enneadocysta spp., with a good representation of Thalassiphora pelagica at the bottom and the middle part of the section (Fig. 6), and the total assemblage suggests a relatively deep, mid-shelf depositional setting for the region.

\subsubsection{Río Los Palos; Loreto Formation}

The samples from this outcrop generally contain diverse, well-preserved and occasionally superabundant dinoflagellate cysts. Two samples (at 115 and $129 \mathrm{~m}$ stratigraphic height) did not contain any dinoflagellate cysts and imply terrestrial depositional environments. The dinoflagellate cyst taxa include Brigantedinium simplex (FO halfway the section), Cleistosphaeridium diversispinosum (LO halfway the section), Octodinium askiniae (LO towards the top of the section), and Turbiosphaera sagena (FO halfway the section; Fig. 7). The presence of Brigantedinium simplex and Turbiosphaera sagena corresponds to the SPDZ15 dinoflagellate cyst zone (Houben et al., 2019), which is dated 35.7 Ma. This is in agreement with isotopic ages from zircon grains from the upper part of the Loreto Formation cropping out in the Brunswick Peninsula indicates an age of $36.48 \pm 0.47 \mathrm{Ma}$ (Otero et al., 2012). Abundant Spinidinium macmurdoense, Vozzhennikovia apertura and Turbiosphaera sagena (Fig. 7) are consistent with a shelf depositional setting.

\subsection{Brunswick Peninsula region}

\subsubsection{Well RGP-03; Tres Brazos Formation}

Abundance of dinoflagellate cysts varies in the 29 samples we examined, but all contain dinoflagellate cysts. Ubiquitous also are terrestrial palynomorphs. Dinoflagellate cyst assemblages are diverse, wellpreserved and contain many stratigraphically significant species: Apectodinium homomorphum, Batiacasphaera cassiculus, Cleistosphaeridium diversispinosum, C. polypetellum, Manumiella rotunda, Membranophoridium perforatum, Octodinium askiniae and Selenopemphix nephroides (Fig. 8; Table 3). The coeval occurrence of these species indicates dinoflagellate cyst zone SPDZ6/ SPDZ7 (late Ypresian; 51.5-49.0 Ma), also supported by the absence of Palaeocystodinium golzowense, of which the LO defines the base of SPDZ6, and the FO's of Turbiosphaera filosa and Enneadocysta dictyostila higher up in the sequence. This implies that Manumiella rotunda, the only taxon that suggests an older age, is either reworked from older strata or has a longer stratigraphic range here than in the Pacific Ocean. Unfortunately, Danea crassimurata, the FO of which defines the SPDZ6/7 zone boundary, was not recognized at this site. The assemblages are dominated by Senegalinium spp., Vozzhennikovial Spinidinium spp., and Deflandrea antarctica (Fig. 8). One of the authors (GRG) recorded very similar assemblages in equivalent sediments of Patagonian Argentina, from outcrops of the lower member of the Río Turbio Formation in Estancia Cancha Carrera (Fig. 1).

\subsubsection{Pecket Mine; Loreto Formation}

While all eight analyzed samples contain abundant terrestrial palynomorphs, only 3 yield dinoflagellate cysts, of which one contained too few for assemblage analyses. This suggests that the succession reflects very near-shore to terrestrial depositional environment. The two productive samples for dinoflagellate cysts contain a diverse assemblage with Brigantedinium simplex, Enneadocysta dictyostila, Glaphyrocysta semitecta, Hystrichokolpoma rigaudiae, Lejeunecysta spp., Operculodinium spp., Selenopemphix brinkhuisii, abundant Spinidinium macmurdoense, and Turbiosphaera sagena (Fig. 9). T. sagena is a distinct morphotype of a T. filose-T. sagena continuum, termed the T. filosa complex. In the Río Turbio area, the FO of T. sagena coincides with the FCO of the T. filosa complex (Guerstein, personal observation, 2020). The abundance of $T$. sagena may make this section slightly younger than that of Río Los Palos at Isla Riesco, where T. sagena only sporadically occurs. This assemblage correlates to the lowermost part of zone RTF4 considered to range from middle to late Priabonian in age (Fig. 2). Zone RTF4 contains the transition from abundant endemic-Antarctic species to dominant cosmopolitan taxa, with high amounts of protoperidinaceans, Nematosphaeropsis spp. This shift in the dinoflagellate 
cyst assemblage composition may be linked to the widening of the Drake Passage and the Tasman Gateway (Sluijs et al., 2003; Sijp et al., 2016) and invigoration of surface currents (Houben et al., 2019), leading to redistribution of heat and potentially moisture. The presence of Selenopemphix brinkhuisii tentatively places this section into the early Oligocene. However, the FO of this species is close to the base of the section overlying a 14 Myr long hiatus at Integrated Ocean Drilling Program Site U1356 at the Wilkes Land Margin, Antarctica (Bijl et al., 2018), which means that the true FO of $S$. brinkhuisii may be older. We did not record other typical markers for the early Oligocene, such as the regionally calibrated Malvinia escutiana (Houben et al., 2011). Moreover, from the Pecket Mine tephra sample, which is stratigraphically below the occurrence of $S$. brinkhuisii, U-Pb results for 45 zircon grains from sample Pecket yield a TuffZirc ${ }^{206} \mathrm{~Pb} /{ }^{238} \mathrm{U}$ age of $36.6 \pm 0.7 \mathrm{Ma}$ (Fig. 9).

\section{Discussion}

\subsection{Ages of formations}

The combined results of dinoflagellate cyst biostratigraphy and $\mathrm{U}-\mathrm{Pb}$ radiometric dating has improved the stratigraphic ages of sedimentary formations of the Austral-Magallanes basin (Fig. 10). Using the results from this study, combined with selected previous biostratigraphic results (e.g., Malumián et al., 2013), it appears that periods of non-deposition or hiatuses occur during the midCampanian-Maastrichtian, Danian, mid-Ypresian, Ypresian-Lutetian and Rupelian.

The mid-Campanian-Maastrichtian hiatus is suspected because the top of the Fuentes Formation is early to mid-Campanian and not Maastrichtian as was suggested earlier (Malumián et al., 2013), while the overlying Rocallosa Formation is late Maastrichtian in age (Malumián et al., 2013). Thomas (1949)
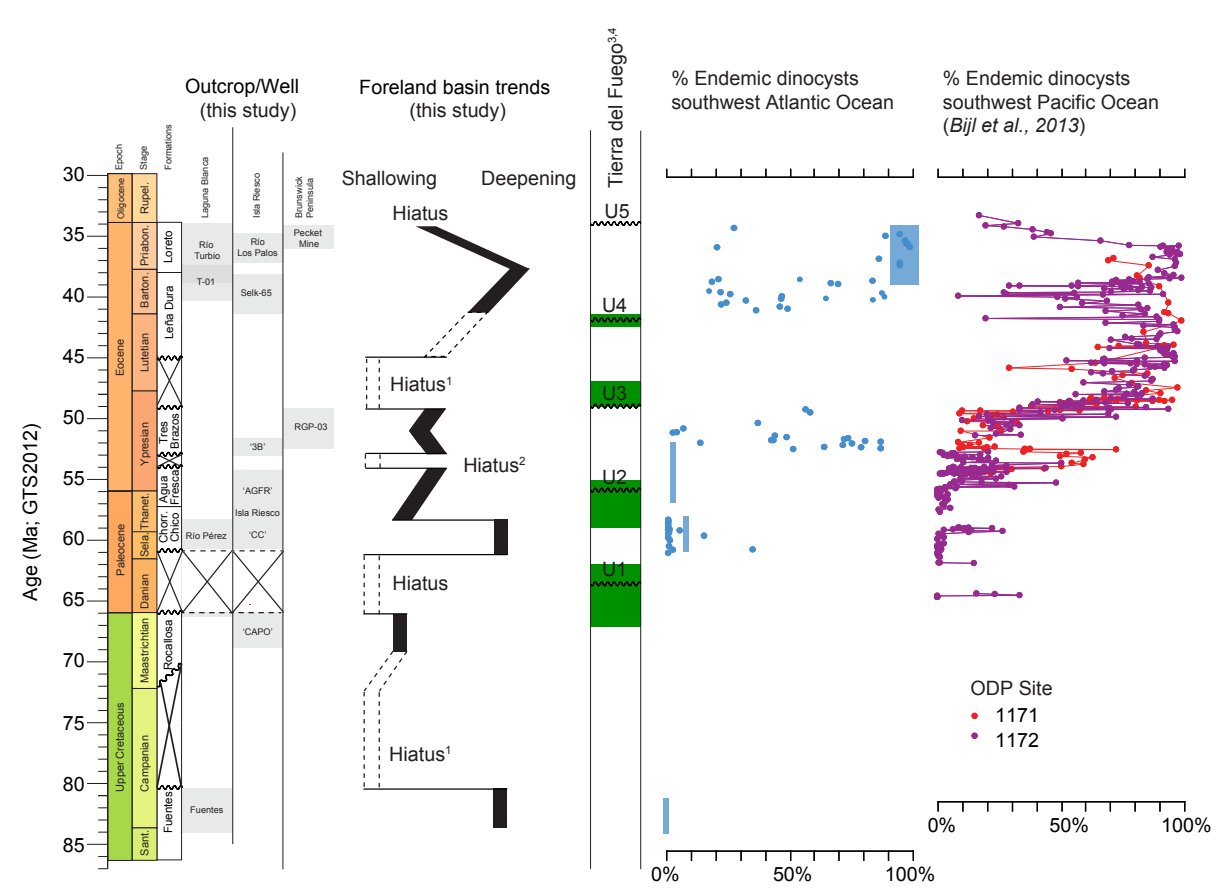

FIG. 10. Stratigraphic interpretation of our study. Epochs, Stages, Formations, and the ages of the studied sections. We deduced a composite record of the relative water depth trends and sedimentary hiatuses, also based on Thomas (1949; hiatus 1) and Malumian et al. (2013; hiatus 2), which compare well known intervals of tectonic compression (green shading) and sedimentary hiatuses (wiggly lines) from the Fuegian Andes (Torres Carbonell et al., 2013, 2014). Based on these age constraints, we present a composite record of the relative abundance of endemic-Antarctic dinoflagellate cysts in Chilean (this study) and Argentinian (Guerstein et al., 2014; González Estebenet et al., 2016; blue boxes) southern Patagonia and compare to the southwest Pacific Ocean (Bijl et al., 2013b, 2014). 
already noted an unconformable superposition of the Rocallosa Formation over Fuentes Formation. The duration of the hiatus is as yet poorly resolved: our study did not successfully date the base of the Rocallosa Formation. Based on the radiometric dates reported in Malumián et al. (2013) for the Rocallosa Formation, we deduce an early Maastrichtian age for the base of that formation.

The boundary between Rocallosa and Chorillo Chico formations. represents a hiatus, which, at our studied sections, straddles the Danian and into the early Selandian ( 66-61 Ma). The boundary to the overlying Agua Fresca Formation was not recovered, but the samples from Agua Fresca at Isla Riesco revealed an age close to the Paleocene/ Eocene boundary. Malumián et al. (2013) presented planktonic and foraminifera dating suggesting the Agua Fresca Formation extends well into the Ypresian.

The early Eocene (52-49 Ma) age for the Tres Brazos Formation from the north shore of Isla Riesco is at odds with previous ages for this formation by Malumián et al. (2013) (45-42 Ma). Typical dinoflagellate cysts for such a young age (e.g., Enneadocysta spp.) are absent in the samples of Tres Brazos Formation we studied (e.g., RGP-3). Although we did not observe the boundary between these units, Malumián et al. (2013) described the boundary between Agua Fresca and Tres Brazos formations as unconformable. Based on our older ages for the Tres Brazos Formation, we here infer that the unconformable contact between Agua Fresca and Tres Brazos formations may not represent much more than $1 \mathrm{Myr}$.

The Ypresian-Lutetian hiatus of around $4 \mathrm{Myr}$ separates the Tres Brazos Formation, with a youngest age of $49 \mathrm{Ma}$, from the Leña Dura Formation, with an oldest possible age of $45 \mathrm{Ma}$, based on the common abundance of Enneadocysta spp. This interpretation disagrees with the proposed by Malumián et al. (2013), who placed these formations conformably. Importantly, however, Thomas (1949) described the boundary between the Tres Brazos and Leña Dura formations as clearly non-conformable, which would support an older age for the Tres Brazos Formation, and a hiatus in between. Based on the continuous common abundance of Enneadocysta spp. (Bijl et al., 2013b), the age of the base of the Leña Dura Formation is not older than $\sim 45 \mathrm{Ma}$, which suggests an Ypresian-Lutetian hiatus of 4 Myr. Collectively, however, the total maximum age span of the Tres Brazos Formation is uncertain and may vary considerably over the region because of tectonic deformation and hiati (e.g., Thomas, 1949; Malumián et al., 2013; Torres Carbonell et al., 2013).

The zircons and dinoflagellate cysts of the Pecket Mine tephra shows a late Eocene (Priabonian) depositional age for the base of the section, consistent with the proposed age for the Loreto Formation by Otero et al. (2012). The zircon sample from well $\mathrm{T}-22$, representing the basal Loreto Formation, has a very strong peak at $38 \mathrm{Ma}$, which is interpreted as a maximum deposition age. This is also in agreement with the dinoflagellate cyst-based ages and corresponds to the age range for the boundary between Leña Dura and Loreto formations. The subordinate Cretaceous peak (11 grains) (Fig. 5), points to the detrital source of the Loreto Formation sediments. These dates agree with source ages suggested by Fosdick et al. (2011), for the Loreto Formation (late Cretaceous, early Cretaceous and late Jurassic), which suggest that by the late Eocene, these Mesozoic rocks were uplifted in the Andean orogeny.

\subsection{Depositional setting and subsidence history}

Late Cretaceous and Cenozoic subsidence of oceanic plates underneath the South American Plate, and the resulting uplift of the Fuegian Andes provided continuous subsidence of the Andean Foreland Basin, which created deep depocentres (Olivero and Martinioni, 2001; Somoza and Ghidella, 2012). Meanwhile, the South American plate was under a constant compressional regime during the CampanianEocene (Maffione et al., 2015), which caused uplift, folding and thrusting of those same sediments (Torres Carbonell et al., 2013, 2014). The interplay between foreland basin subsidence, compression in the overriding plate, and sediment supply thus governed sedimentation history in the foreland basin.

We infer that the hiatuses in the sedimentary succession signify time intervals before which sedimentation rates had exceeded foreland basin deepening. For instance, while the Leña Dura Formation consists of relatively deep-marine sediments, the overlying Loreto Formation seems to grade from marine coastal into a terrestrial (fluvial) depositional regime towards the latest Eocene. Apparently, either subsidence stalled, sediment supply rates increased and/or compression invigorated that caused a decrease in accommodation space in the foreland basin. 
In contrast, during the Maastrichtian, ThanetianYpresian, and Bartonian-Priabonian, subsidence rates exceeded sedimentation rates and sediment supply. We base this on the gradual fining upwards of Rocallosa Formation, and stratigraphically expanded shallow-marine sediment packages in the Paleocene Chorrillo Chico and Eocene Agua Fresca, Leña Dura and Loreto formations, respectively, with the latter transitions into non-marine deposits (Figs. 9, 10). The deepest marine successions were deposited during the Selandian and Bartonian deposition of the Chorrillo Chico and Leña Dura formations: sediments are consistently marine, mid-shelf, without interruptions of terrestrial sediments. This suggests that subsidence rates reached a maximum during these time intervals. The timing of a deep foreland basin in the Bartonian corresponds with a switch in sediment provenance: detrital input from eroding young Patagonian batholiths was dammed by the uplift of older Darwin Cordillera thrust sheets inboard of these batholiths (Barbeau et al., 2009). Either the switch in detrital source decreased sediment supply, or the increased uplift of the Darwin-Cordillera complex deepened the foreland basin. Although the timing of a deep foreland basing coincides with this provenance shift, no such shift is observed that could explain the deep mid-Paleocene foreland basin. Throughout the Upper Cretaceous to middle Eocene, sand provenance is consistently from the Patagonian-Fuegan magmatic arc (Barbeau et al., 2009).

Interestingly, the timing of the hiatuses we infer throughout the late Cretaceous-early Oligocene correspond to those found independently in the Fuegian Andes foreland (Torres Carbonell et al., 2013, 2014; Fig. 10) for which also detailed reconstructions of the compressional phases were made. The largescale spatial consistency between our three study areas and the Fuegian foreland suggests that these hiatuses were forced by tectonics and basin fill dynamics rather than local disturbances at our individual study sections.

In turn, our reconstructed foreland basin depth history is the product of the uplift Andean orogeny, which in turn is governed by subduction rates of the oceanic plates. Tectonic reconstructions reveal fast subduction of the Phoenix plate from $47 \mathrm{Ma}$ onwards (Somoza and Ghidella, 2012), which increased Andean uplift rates in the region and in that process increased subsidence rates in the foreland basin, creating more marine depositional settings at that time. Indeed, our foreland basin depth reconstruction shows a noticeable deepening between the early Eocene Tres Brazos Formation and the mid-middle Eocene Leña Dura Formation (Fig. 10), in line with signs of increased subsidence and thereby, more uplift. Whether the relatively deep marine facies in the mid-Paleocene Andean Foreland basin is also associated with increased subduction rates is still elusive, but our results certainly suggest this.

\subsection{Antarctic-endemic dinoflagellate cyst community}

The results from Chilean Patagonia presented here show a remarkably similar abundance and evolution of endemic dinoflagellate cysts to that in the southwest Pacific Ocean (Figs. 10, 11): sporadic occurrences of elements of the endemic community during the Paleocene (Spinidinium and Vozzhennikovia), a brief interval of higher abundances of endemic dinoflagellate cysts during the mid-early Eocene, and then a pronounced proliferation of endemic dinoflagellate cysts from around $52 \mathrm{Ma}$ onwards (although the latter is poorly constrained due to incomplete stratigraphic coverage of the late Ypresian). Previous palynological studies of middle to upper Eocene units from the Austral Basin in Argentina (Fig. 11; Guerstein et al., 2014; González Estebenet et al., 2016) showed a good analogy of the evolution of the Antarctic-endemic assemblage in the southwest Atlantic Ocean with that proposed for the southwest Pacific Ocean by Bijl et al. (2013a). Also, the interruption of dominance of endemic dinoflagellate cysts in the middle Eocene as was seen in the southwest Pacific Ocean (Bijl et al., 2011, 2013a), seems to be replicated in the southwest Atlantic (Fig. 10).

Even on a species level, there is no noticeable distinction between dinoflagellate cyst assemblages from the southwest Pacific and the southwest Atlantic. In fact, dinoflagellate cyst assemblages from our study are much more similar to those from the southwest Pacific than to those from the southeast Indian Ocean (Bijl et al., 2011; Houben et al., 2019), despite the suggested oceanographic connection of the southwest Atlantic and southeast Indian Ocean by the large proto-weddell Gyre (Huber et al., 2004; Sijp et al., 2016).

The circum-Antarctic similarity of assemblage character and species composition has several 


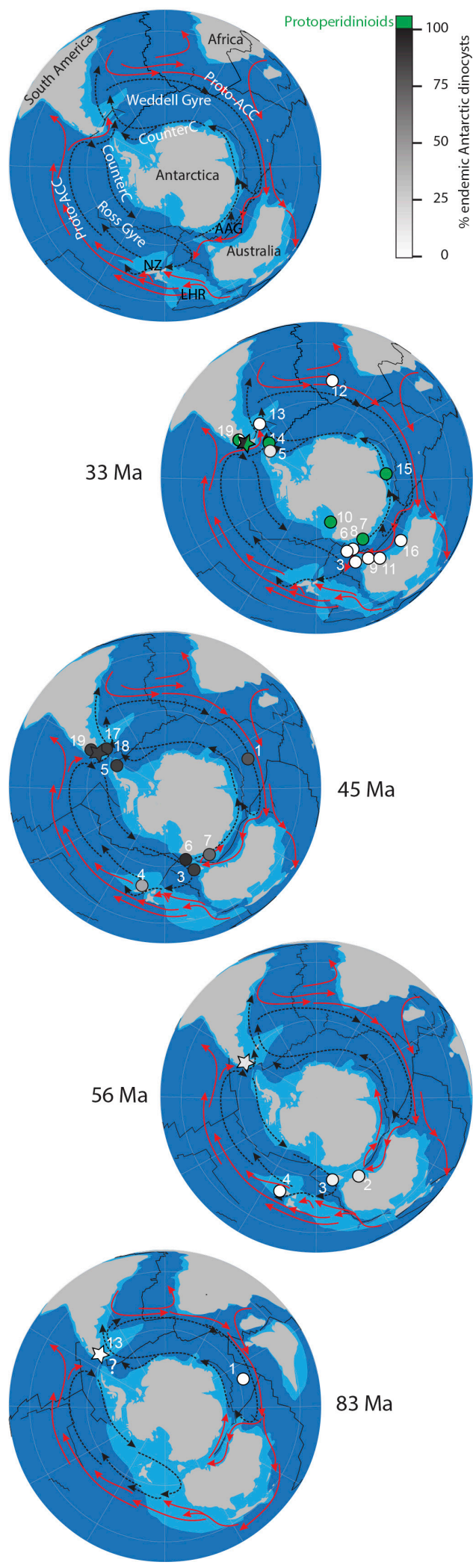

FIG. 11. Paleogeography of the Southern Hemisphere, for $83 \mathrm{Ma}, 56 \mathrm{Ma}$, $45 \mathrm{Ma}$, and $33 \mathrm{Ma}$. The plate circuit used is according to Seton et al. (2012) on a paleomagnetic reference frame (mid-ocean ridges are indicated in solid black lines). Study area indicated with a star. Arrows indicate low-latitude-derived, subtropical surface currents (red) and Antarctic-derived, polar currents (dashed black). Dots represent locations of dinoflagellate cyst assemblage data from $\sim 5$ Myr bins surrounding the time of the respective paleogeographic reconstruction: 85-80 Ma, 58-53 Ma, 47-42 Ma, 34-30 Ma. NZ: New Zealand, LHR: Lord Howe Rise, CounterC: countercurrent, AAG: Australo-Antarctic Gulf, protoACC: protoAntarctic Circumpolar Current. Fill gray-scale indicates relative abundance of endemic dinoflagellate cysts, green fill indicates dominance of protoperidinioid dinoflagellate cysts, based on the original papers or reassessed as in Bijl et al. (2011): 1. Site 748 (Mao and Mohr, 1992; P.K. Bijl, personal observation, 2020); 2. Otway Basin, Australia (Frieling et al., 2018); 3. ODP Site 1172 (Brinkhuis et al., 2003b; Bijl et al., 2013b; Houben et al., 2019); 4. Waipara, Tawanui, Ashley Mudstone and Hampden Beach (Crouch and Brinkhuis, 2005; Hollis et al., 2014; Crouch et al., 2014; Dallanave et al., 2016; Cramwinckel et al., 2019); 5. Seymour Island (Wrenn and Hart, 1988; Douglas et al., 2014; Aménabar et al., 2019); 6. ODP Site 1171 (Bijl et al., 2013b); 7. IODP Site U1356 (Bijl et al., 2013b); 8. ODP Site 1170 (Cramwinckel et al., 2019); 9. ODP Site 1168 (Brinkhuis et al., 2003a; Sluijs et al., 2003); 10. CRP-3 (Houben et al., 2013); 11. Browns Creek (Houben et al., 2019); 12. ODP Site 1090 (Warnaar, 2006); 13. ODP Site 511 (Houben et al., 2011, 2019); 14. ODP Site 696 (Houben et al., 2013, 2019); 15. ODP Site 739 (Houben et al., 2013); 16. ODP Site 1128 (Houben et al., 2019); 17. Leticia Formation, Tierra del Fuego (Guerstein et al., 2008); 18. Man Aike Formation (Guerstein et al., 2014); 19. Río Turbio Formation (González Estebenet et al., 2016).

implications. First of all, it precludes geographical isolation of the southwest Pacific Ocean-notably through closure by the poorly constrained bathymetric heights of Zealandia/Lord Howe Rise-as cause for the proliferation of endemism in the Southern Ocean (Bijl et al., 2011; Cramwinckel et al., 2019; Fig. 11). This makes explaining why endemism in the Southern Ocean occurs more difficult. Secondly, it suggests that both southwest Atlantic and southwest Pacific regions were in oceanographic communication with each other. For the middle and late Eocene, this connection is most likely through the counterclockwise flowing Counter Current along coastal Antarctica and connects the proto-Ross Gyre with the protoWeddell Gyre (Fig. 11; Guerstein et al., 2010; Bijl et al., 2013a; Houben et al., 2019). Ocean model simulations have suggested that the counter-current was most effectively transporting surface waters from the southwest Pacific Ocean westward when Drake Passage was closed (Sijp et al., 2016), which 
indeed seems to have been the case at least until $41 \mathrm{Ma}$ (Scher and Martin, 2006). However, during the Paleocene and early Eocene, the counter current was not yet established as the Tasmanian Gateway was seemingly still closed (Exon et al., 2004; Bijl et al., 2013a), yet endemic species were present in both the southwest Pacific (Bijl et al., 2011, 2013a, b) and southwest Atlantic oceans (this study). While Wrenn and Beckmann (1982) interpreted these patterns as evidence for a transantarctic seaway between East and West Antarctica, the latest paleotopographic reconstructions of Antarctica (e.g., Wilson et al., 2012; Paxman et al., 2019) leave little room for a marine transantarctic connection. The easiest way the synchronous proliferation of dinoflagellate cyst endemism in both South Atlantic and Pacific basins is that Drake Passage must have been shallowly open throughout at least the Paleocene and Eocene. This would make the eastward throughflow through Drake Passage as reconstructed by Scher and Martin (2006) reflective of a widening/deepening of Drake Passage, allowing also deep waters of both basins to be connected. This interpretation corroborates with the distinctly different sediment provenance signatures in the Antarctic Larsen basin and the then adjacent Austral basin in Patagonia, which also tentatively suggested early tectonic separation (Barbeau, 2013).

\section{Conclusions}

Our study places key sedimentary formations in the South Patagonian foreland basin into an absolute time frame, identifies and dates phases of accelerated subsidence of these basins, and reconstructs the paleoceanographic consequences of Campanian-Eocene tectonic events. We recognize regional sedimentary hiatuses spanning the late Campanian, early-to mid-Paleocene, mid-Eocene and latest Eocene-early Oligocene, indicating phases of increased sedimentation in and/or ceased subsidence/ increased compression of the foreland basin. The time intervals in between these compressional phases are characterized by thick successions of mid-to inner shelf marine and terrestrial sedimentary regimes, notably the early Campanian, mid-Paleocene, Paleocene-Eocene boundary and middle Eocene, which represent phases of increased subsidence. The dinoflagellate cyst assemblages suggest the region was under the influence of the Antarctic-derived suface waters driven by the western boundary currents of the proto-Weddell gyre throughout. Furthermore, the consistent evolution of endemicAntarctic dinoflagellate cysts in both the southwest Pacific and the southwest Atlantic suggests continued oceanic connectivity since the Paleocene, perhaps through a continuous shallow southern opening in an incipiente Drake Passage.

\section{Acknowledgements}

The authors thank N. Welters, G. Dammers and N. Janssen for processing samples for palynology. We thank T. Markus for help drafting figure 1. The authors thank the kind hospitality and assistance from the people at Enap during the collection of field samples, and Ingeniería Civil Vicente Company for access to sites and core material. PKB acknowledges funding for this project through NWO VENI grant No. 863.13.002. SC was funded by PI-UNRN 40A559. AE was funded by Conicyt, Fondecyt Project 1151146. We thank J. Riding an the editor for their reviews.

PKB designed the research. PKB, SC, EASJ and AS collected the sediment samples. SC and EASJ provided lithological column information. AE and EASJ provided $\mathrm{U}-\mathrm{Pb}$ ages. GRG and $\mathrm{CRA}$ contributed to the discussion and writing of the paper. PKB analysed the samples for dinoflagellate cysts and wrote the paper with input from all authors. AS thanks the European Research Council for Consolidator Grant 771497 (SPANC) and the Netherlands Earth System Science Centre, funded through a Gravitation Grant by the Netherlands Ministry of Education, Culture and Science and the Dutch Research Council NWO.

The authors declare no competing financial interests.

\section{References}

Amenábar C.R.; Montes, M.; Nozal, F.; Santillana, S. 2019. Dinoflagellate cysts of the La Meseta Formation (middle to late Eocene), Antarctic Peninsula: Implications for biostratigraphy, paleoceanography and palaeoenvironment. Geological Magazine 157 (3): 351-366. doi: 10.1017/S0016756819000591.

Askin, R.A. 1988. Campanian to Paleocene palynological succession of Seymour and adjacent islands, northeastern Antarctic Peninsula. Geological Society of America, Memoir 169: 131-153.

Awad, W.K.; Oboh-Ikuenobe, F.E. 2016. Early Paleogene dinoflagellate cysts from ODP Hole 959D, Côte d'IvoireGhana Transform Margin, West Africa: New species, biostratigraphy and paleoenvironmental implications. Journal of African Earth Sciences 123: 123-144. 
Barbeau, D.L. 2013. Exhumational History of the Margins of Drake Passage from Thermochronology and Sediment Provenance. Tectonic, Climatic, and Cryospheric Evolution of the Antarctic Peninsula 63: 35-9. doi: 10.1029/2010SP000992.

Barbeau, D.L.; Olivero, E.B.; Swanson-Hysell, N.L.; Zahid, K.M.; Murray, K.E.; Gehrels, G.E. 2009. Detrital-zircon geochronology of the eastern Magallanes foreland basin: Implications for Eocene kinematics of the northern Scotia Arc and Drake Passage. Earth and Planetary Science Letters 284 (3-4): 489-503. doi: 10.1016/j.eps1.2009.05.014.

Barker, P.F.; Thomas, E. 2004. Origin, signature and paleoclimatic influence of the Antarctic Circumpolar Current. Earth Science Reviews 66: 143-162.

Barker, P.F.; Dieckmann, B.; Escutia, C. 2007. Onset of Cenozoic Antarctic glaciation.Deep Sea Research, Part II: Topical Studies in Oceanography 54 (21-22): 2293-2307. doi: 10.1016/j.dsr2.2007.07.027.

Bijl, P.K.; Pross, J.; Warnaar, J.; Stickley, C.E.; Huber, M.; Guerstein, R.; Houben, A.J.P.; Sluijs, A.; Visscher, H.; Brinkhuis, H. 2011. Environmental forcings of Paleogene Southern Ocean dinoflagellate biogeography. Paleoceanography 26: PA1202.

Bijl, P.K.; Bendle, A.P.J.; Bohaty, S.M.; Pross, J.; Schouten, S.; Tauxe, L.; Stickley, C.E.; McKay, R.M.; Röhl,U.; Olney, M.; Sluijs, A.; Escutia, C.; Brinkhuis, H.; Expedition 318 scientists. 2013a. Eocene cooling linked to early flow across the Tasmanian Gateway. Proceedings of the National Academy of Sciences of the United States of America 110: 9645-9650.

Bijl, P.K.; Sluijs, A.; Brinkhuis, H. 2013b. A magnetochemo-stratigraphically calibrated dinoflagellate cyst zonation of the early Paleogene South Pacific Ocean. Earth-Science Reviews 124: 1-31.

Bijl, P.K.; Sluijs, A.; Brinkhuis, H. 2014. Erratum to "A magneto-and chemostratigraphically calibrated dinoflagellate cyst zonation of the early Paleogene South Pacific Ocean" [Earth Science Reviews 124 (2013): 1-31]. Earth Science Reviews 134: 160-163. doi: 10.1016/j.earscirev.2014.03.010.

Bijl, P.K.; Houben, A.J.P.; Bruls, A.; Pross, J.; Sangiorgi, F. 2018. Stratigraphic calibration of Oligocene-Miocene organic-walled dinoflagellate cysts from offshore Wilkes Land, East Antarctica, and a zonation proposal. Journal of Micropalaeontology 37: 105-138.

Bohaty, S.M.; Zachos, J.C. 2003. Significant Southern Ocean warming event in the late middle Eocene. Geology 31: 1017-1020.
Bohaty, S.M.; Zachos, J.C.; Florindo, F.; Delaney, M.L. 2009. Coupled greenhouse warming and deep-sea acidification in the Middle Eocene. Paleoceanography and Paleoclimatology 24 (2): PA2207. doi: 10.1029/2008PA001676.

Bowman, V.C.; Francis, J.E.; Riding, J.B.; Hunter, S.J.; Haywood, A.M. 2012. A latest Cretaceous to earliest Paleogene dinoflagellate cyst zonation from Antarctica, and implications for phytoprovincialism in the high southern latitudes. Review of Palaeobotany and Palynology 171: 40-56.

Brinkhuis, H.; Biffi, U. 1993. Dinoflagellate cyst stratigraphy of the Eocene/Oligocene transition in Central Italy. Marine Micropaleontology 22: 131-183.

Brinkhuis, H.; Bujak, J.P.; Smit, J.; Versteegh, G.J.M.; Visscher, H. 1998. Dinoflagellate-based sea surface temperature reconstructions across the CretaceousTertiary boundary. Palaeogeography, Palaeoclimatology, Palaeoecology 141: 67-83.

Brinkhuis, H.; Munsterman, D.M.; Sengers, S.; Sluijs, A.; Warnaar, J.; Williams, G.L. 2003a. Late Eocene to Quaternary dinoflagellate cysts from ODP Site 1168, off western Tasmania. In Proceedings of the Ocean Drilling Program, Scientific Results 189: 1-48 (Online). United States Government Printing Office, College Station, TX (Ocean Drilling Program): 1-36. doi:10.2973/odp.proc.sr.189.105.2003.

Brinkhuis, H.; Sengers, S.; Sluijs, A.; Warnaar, J.; Williams, G.L. 2003b. Latest Cretaceous to earliest Oligocene, and Quaternary dinoflagellates from ODP Site 1172, East Tasman Plateau. In Proceedings of the Ocean Drilling Program, Scientific Results (Exon, N.; Kennett, J.P.; editors). United States Government Printing Office, College Station 189: 1-48 (Online). Texas.

Brinkhuis, H.; Schouten, S.; Collinson, M.E.; Sluijs, A.; Sinninghe Damsté, J.S.; Dickens, G.R.; Huber, M.; Cronin, T.M.; Onodera, J.; Takahashi, K.; Bujak, J.P.; Stein, R.; Burg, J.V.D.; Eldrett, J.S.; Harding, I.C.; Lotter, A.F.; Sangiorgi, F.; Konijnenburg-Cittert, H.V.; Leeuw, J.W.D.; Matthiessen, J.; Backman, J.; Moran, K.; Expedition 302 Scientists. 2006. Episodic fresh surface waters in the Eocene Arctic Ocean. Nature 441: 606-609.

Brown, S.; Downie, C. 1984. Dinoflagellate cyst biostratigraphy of late Paleocene and early Eocene sediments from Holes 552, 553A, and 555, Leg 81, Deep Sea Drilling Project (Rockall Plateau). Initial Reports DSDP, Leg 81, Southampton to Azores: 565 579. doi: 10.2973/dsdp.proc.81.113.1984. 
Bujak, J.P.; Mudge, D.C. 1994. A high-resolution North Sea Eocene dinocyst zonation. Journal of the Geological Society 151 (3): 449-462. London.

Chang, Z.; Vervoort, J.D.; McClelland, W.C.; Knaack, C. 2006. U-Pb dating of zircon by LA-ICP-MS. Geochemistry, Geophysics, Geosystems 7: Q05009.

Charrier, R.; Lahsen, A. 1969. Stratigraphy of Late Cretaceous-Early Eocene of Seno Skyring-Estrecho of Magellan area, Magallanes Province, Chile. American Association of Petroleum Geologists, Bulletin 53 (3): 568-590.

Charrier, R.; Pinto, L.; Rodríguez, M.P. 2007. Tectonostratigraphic evolution of the Andean Orogen in Chile. In The Geology of Chile (Moreno, T.; Gibbons, W.; editors). The Geological Society, Special Publication: 21-114. London.

Cookson, I.C.; Cranwell, L.M. 1967. Lower Tertiary microplankton, spores and pollen grains from southernmost Chile. Micropaleontology 13: 204-216.

Costa, L.I.; Davey, R.J. 1992. Dinoflagellate cysts of the Cretaceous system. In A stratigraphix index of dinoflagellate cysts (Powell, A.J.; editor). British Micropaleontological Society Publication Series: 99-154.

Cramwinckel, M.J.; Huber, M.; Kocken, I.J.; Agnini, C.; Bijl, P.K.; Bohaty, S.M.; Frieling, J.; Goldner, A.; Hilgen, F.J.; Kip, E.L.; Peterse, F.; Van Der Ploeg, R.; Röhl, U.; Schouten, S.; Sluijs, A. 2018. Synchronous tropical and polar temperature evolution in the Eocene letter. Nature 559: 382-386.

Cramwinckel, M.J.; Woelders, L.; Huurdeman, E.P.; Peterse, F.; Gallagher, S.J.; Pross, J.; Burgess, C.; Reichart, G.J.; Sluijs, A.; Bijl, P.K. 2019. Surfacecirculation change in the Southern Ocean across the Middle Eocene Climatic Optimum: inferences from dinoflagellate cysts and biomarker paleothermometry. Climate of the Past Discussions 2019: 1-34.

Crouch, E.M.; Brinkhuis, H. 2005. Environmental change across the Paleocene-Eocene transition from eastern New Zealand: A marine palynological approach. Marine Micropaleontology 56: 138-160.

Crouch, E.M.; Willumsen, P.S.; Kulhanek, D.K.; Gibbs, S. 2014. A revised Paleocene (Teurian) dinoflagellate cyst zonation from eastern New Zealand. Palaeogeography, Palaeoclimatology, Palaeoecology 202: 47-79.

Dallanave, E.; Bachtadse, V.; Crouch, E.M.; Tauxe, L.; Shepherd, C.L.; Morgans, H.E.G.; Hollis, C.J.; Hines, B.R.; Sugisaki, S. 2016. Constraining early to middle Eocene climate evolution of the southwest Pacific and Southern Ocean. Earth and Planetary Science Letters 433: 380-392.
Douglas, P.M.J.; Affek, H.P.; Ivany, L.C.; Houben, A.J.P.; Sijp, W.P.; Sluijs, A.; Schouten, S.; Pagani, M. 2014. Pronounced zonal heterogeneity in Eocene southern high-latitude sea surface temperatures. Proceedings of the National Academy of Sciences of the United States of America 111 (18): 6582-6587.

Eagles, G.; Livermore, R.A. 2002. Opening history of Powell Basin, Antarctic Peninsula. Marine Geology 185: 195-205.

Egger, L.M.; Sliwinska, K.K.; van Peer, T.E.; Liebrand, D.; Lippert, P.C.; Friedrich, O.; Wilson, P.A.; Norris, R.D.; Pross, J. 2016. Magnetostratigraphically-calibrated dinoflagellate cyst bioevents for the uppermost Eocene to lowermost Miocene of the western North Atlantic (IODP Expedition 342, Paleogene Newfoundland sediment drifts). Review of Palaeobotany and Palynology 234: 159-185.

Eshet, Y:; Moshkovitz, S.; Habib, D.; Benjamini, C.; Magaritz,M. 1992. Calcareous nannofossil and dinoflagellate stratigraphy across the Cretaceous/Tertiary boundary at Hor Hahar, Israel. Marine Micropaleontology 18: 199-228.

Exon, N.F.; Brinkhuis, H.; Robert, C.M.; Kennett, J.P.; Hill, P.J.; Macphail, M.K. 2004. Tectono-Sedimentary History of Uppermost Cretaceous Through Oligocene Sequences from the Tasmanian Region, A Temperate Antarctic Margin. In The Cenozoic Southern Ocean: Tectonics, Sedimentation, and Climate Change between Australia and Antarctica (Exon, N.F.; Kennett, J.P.; Malone, M.J.; editors). Geophysical Monograph Series 151: 319-344.

Firth, J.V. 1996. Upper middle Eocene to Oligocene dinoflagellate biostratigraphy and assemblage variations in hole 913B, Greenland Sea. In Proceedings of the Ocean Drilling Program (Thiede, J.; Myrhe, A.M.; Firth, J.V.; Johnson, G.L.; Ruddiman, W.F.; editors). Scientific Results 151: 203-242.

Fosdick, J.C.; Romans, B.W.; Fildani, A.; Bernhardt, A.; Calderón, M.; Graham, S. 2011. Kinematic evolution of the Patagonian retroarc fold-and-thrust belt and Magallanes foreland basin, Chile and Argentina, $51^{\circ} 30^{\prime} \mathrm{S}$. Geological Society of America, Bulletin 123 (9-10): 1679-1698.

Frieling, J.; Sluijs, A. 2018. Towards quantitative environmental reconstructions from ancient non-analogue microfossil assemblages: Ecological preferences of Paleocene-Eocene dinoflagellates. Earth-Science Reviews 185: 956-973.

Frieling, J.; Iakovleva, A.I.; Reichart, G.-J.; Aleksandrova, G.N.; Gnibidenko, Z.N.; Schouten, S.; Sluijs, A. 2014. 
Paleocene-Eocene warming and biotic response in the epicontinental West Siberian Sea. Geology 42 (9): 767-770.

Frieling, J.; Huurdeman, E.P.; Rem, C.C.M.; Donders, T.H.; Pross, J.; Bohaty, S.M.; Holdgate, G.R.; Gallagher, S.J.; McGowran, B.; Bijl, P.K. 2018. Identification of the Paleocene-Eocene boundary in coastal strata in the Otway Basin, Victoria, Australia. Journal of Micropalaeontology 37: 317-339.

García, F. 1952. Geología de superficie de la parte noroeste de la Isla Riesco. Informe Inédito, Empresa Nacional de Petróleo (ENAP). Santiago.

González Estebenet, M.S.; Guerstein, G.R.; Rodríguez Raising, M.E.; Ponce, J.J.; Alperín, M.I. 2016. Dinoflagellate cyst zonation for the middle to upper Eocene in the Austral Basin, southwestern Atlantic Ocean: Implications for regional and global correlation. Geological Magazine 154: 1022-1036.

Gradstein, F.M.; Kristiansen, I.L.; Loemo, L.; Kaminski, M.A. 1992. Cenozoic foraminiferal and dinoflagellate cyst biostrtigraphy of the central North Sea. Micropaleontology 38-2: 101-137.

Gradstein, F.M.; Ogg, J.G.; Schmitz, M.D.; Ogg, G.M. 2012. The Geologic Time Scale 2012. Elsevier Publishing Company, 2 Volume (Set 1-2): 1-1144.

Guerstein, G.R.; Guler, M.V.; Williams, G.L.; Fensome, R.A.; Chiesa, J.O. 2008. Middle Palaeogene dino-flagellate cysts from Tierra del Fuego, Argentina: Biostratigraphy and palaeoenvironments. Journal of Micropalaeontology 27 (1): 75-94.

Guerstein, G.R.; Guler, M.V.; Brinkhuis, H.; Warnaar, J. 2010. Mid-Cenozoic paleoclimatic and paleoceanographic trends in the southwestern Atlantic Basins: a dinoflagellate view. In The Paleontology of Gran Barranca: Evolution and Environmental Change through the Middle Cenozoic of Patagonia (Madden, R.H.; Carlini, A.A.; Vucetich, M.G.; Kay, R.F.; editors). Cambridge University Press: 1022-1036. London.

Guerstein, G.R.; González Estebenet, M.S.; Alperín, M.I.; Casadio, S.A.; Archangelsky, S. 2014. Correlation and paleoenvironments of middle Paleogene marine beds based on dinoflagellate cysts in southwestern Patagonia, Argentina. Journal of South American Earth Sciences 52: 166-178.

Head, M.J.; Norris, G. 1989. Palynology and dinoflagellate cyst stratigraphy of the Eocene and Oligocene in ODP Leg 105, Hole 647A, Labrador Sea. Proceedings Ocean Drilling Program, Scientific Results, ODP, Leg 105, Baffin Bay and Labrador Sea: 515-550.
Helby, R.; Morgan, R.; Partridge, A.D. 1987. A palynological zonation of the Australian Mesozoic. In Studies in Australian Mesozoic Palynology (Jell, P.A.; editor).Association of Australasian Palaeontologists Memoir 4: 1-94.

Hill, P.J.; Exon, N.F. 2004. Tectonics and Basin Development of the Offshore Tasmanian Area; Incorporating Results from Deep Ocean Drilling. In The Cenozoic Southern Ocean; Tectonics, Sedimentation and Climate Change Between Australia and Antarctica (Exon, N.F.; Kennett, J.P.; Malone, M.; editors). American Geophysical Union, Geophysical Monograph Series 151: 19-42. Washington.

Hoffstetter, R.; Fuenzalida, H.; Cecioni, G. 1957. Chili. In Lexique Stratigraphique International. Amérique Latine. Centre National de la Recherche Scientifique 5 (7): 444 p. París.

Hollis, C.J.; Tayler, M.J.S.; Andrew, B.; Taylor, K.W.; Lurcock, P.; Bijl, P.K.; Kulhanek, D.K.; Crouch, E.M.; Nelson, C.S.; Pancost, R.D.; Huber, M.; Wilson, G.S.; Ventura, G.T.; Crampton, J.S.; Schiøler, P.; Phillips, A. 2014. Organic-rich sedimentation in the South Pacific Ocean associated with Late Paleocene climatic cooling. Earth-Science Reviews 134: 81-97.

Houben, A.J.P.; Bijl, P.K.; Guerstein, G.R.; Sluijs, A.; Brinkhuis, H. 2011. Malvinia escutiana, a new biostratigraphically important Oligocene dinoflagellate cyst from the Southern Ocean. Review of Palaeobotany and Palynology 165: 175-182.

Houben, A.J.P.; Bijl, P.K.; Pross, J.; Bohaty, S.M.; Passchier, S.; Stickley, C.E.; Röhl, U.; Sugisaki, S.; Tauxe, L.; Van De Flierdt, T.; Olney, M.; Sangiorgi, F.; Sluijs, A.; Escutia, C.; Brinkhuis, H. 2013. Reorganization of Southern Ocean plankton ecosystem at the onset of Antarctic glaciation. Science 340: 341-344.

Houben, A.J.P.; Bijl, P.K.; Sluijs, A.; Schouten, S.; Brinkhuis, H. 2019. Late Eocene Southern Ocean cooling and invigoration of circulation preconditioned Antarctica for full-scale glaciation. Geochemistry, Geophysics, Geosystems 20 (5): 2214-2234.

Huber, M.; Brinkhuis, H.; Stickley, C.E.; Döös, K.; Sluijs, A.; Warnaar, J.; Schellenberg, S.A.; Williams, G.L. 2004. Eocene circulation of the Southern Ocean: Was Antarctica kept warm by subtropical waters? Paleoceanography 19: p. PA4026.

Jackson, S.E.; Pearson, N.J.; Griffin, W.L.; Belousova, E.A. 2004. The application of laser ablation-inductively coupled plasma-mass spectrometry to in situ $\mathrm{U}-\mathrm{Pb}$ zircon geochronology. Chemical Geology 211: 47-69. 
Lagabrielle, Y.; Goddéris, Y.; Donnadieu, Y.; Malavieille, J.; Suárez, M. 2009. The tectonic history of Drake Passage and its possible impacts on global climate. Earth and Planetary Science Letters 279: 197-211.

Leereveld, H. 1997. Upper Tithonian-Valanginian (Upper Jurassic-Lower Cretaceous) dinoflagellate cyst stratigraphy of the western Mediterranean. Cretaceous Research 18: 385-420.

Livermore, R.; Nankivell, A.; Eagles, G.; Morris, P. 2005. Paleogene opening of Drake Passage. Earth and Planetary Science Letters 236: 459-470.

Ludwig, K.R. 2003. User's manual for Isoplot/Ex version 3.0, a geochronological toolkit for Microsoft Excel. Berkeley Geochronology Center, Special Publication 4: 72 p. California.

Maffione, M.; Hernández-Moreno, C.; Ghiglione, M.C.; Speranza, F.; van Hinsbergen, D.J.J.; Lodolo, E. 2015. Constraints on deformation of the Southern Andes since the Cretaceous from anisotropy of magnetic susceptibility. Tectonophysics 665: 236-250.

Malumián, N.; Hromic T.; Náñez, C. 2013. El Paleógeno de la Cuenca de Magallanes: Biostratigrafía y discontinuidades. Anales del Instituto de la Patagonia (Chile) 41 (1): 29-52. doi: 10.4067/S0718-686X2013000100003.

Mao, S.; Mohr, B.A.R. 1992. Late Cretaceous dinoflagellate cysts (? Santonian-Maestrichtian) from the Southern Indian Ocean (Hole 748C). In Proceedings of the Ocean Drilling Program, Scientific Results (Wise, S.W.; Schlich, R.; editors). Ocean Drilling Program, College Station, TX 120: 307-341. doi: 10.2973/odp.proc. sr.120.190.1992.

Marenssi, S.; Guler, V.; Casadio, S.; Guerstein, R.; Papú, O. 2004. Sedimentology and palynology of the Calafate Formation (Maastrichtian), Austral Basin, Southern Patagonia, Argentina. Cretaceous Research 25: 907-918.

Masure, E.; Rauscher, R.; Dejax, J.; Schuler, M.; Ferre, B. 1998. Cretaceous-Paleocene palynology from the Cote D'ivoire-Ghana Transform Margin, sites 959, 960, 961, and 962. In Proceedings of the Ocean Drilling Program (Mascle, J.; Lohmann,G.P.; Moullade, M.; editors). Scientific Results 159: 253-276.

Mohr, B.A.R.; Mao, S. 1997. Maastrichtian dinoflagellate cyst floras from Maud Rise and Georgia Basin (Southern Ocean): Their Stratigraphic and Palaeoenvironmental implications. Palynology 21: 41-65.

Natland, M.L.; González, E.P.; Cañón, A.; Ernst, M. 1974. A System of Stages for correlation of Magallanes Basin Sediments. Geological Society American, Memoir 139: 1-125.
Olivero, E.B.; Martinioni, D.R. 2001. A review of the geology of the Argentinian Fuegian Andes. Journal of South American Earth Sciences 14: 175-188.

Orsi, A.H.; Whitworth III, T.; Nowlin Jr., W.D. 1995. On the meridional extent and fronts of the Antarctic Circumpolar Current. Deep-Sea Research, Part I 42 (5): 641-673.

Otero, R.A.; Torres, T.; Le Roux, J.P.; Hervé, F.; Mark Fanning, C.; Yury-Yáñez, R.E.; Rubilar-Rogers, D. 2012. A Late Eocene age proposal for the Loreto Formation (Brunswick Peninsula, southernmost Chile), based on fossil cartilaginous fishes, paleobotany and radiometric evidence. Andean Geology 39: 180-200. doi: 10.5027/andgeoV39N1-a09.

Paces, J.B.; Miller, J.D. 1993. Precise U-Pb ages of Duluth Complex and related mafic intrusions, northeastern Minnesota: Geochronological insights to physical, petrogenetic, paleomagnetic, and tectonomagmatic processes associated with the $1.1 \mathrm{Ga}$ Midcontinent Rift System. Journal of Geophysical Research, Solid Earth 98: 13997-14013.

Paton, C.; Woodhead, J.D.; Hellstrom, J.C.; Hergt, J.M.; Greig, A.; Maas, R. 2010. Improved laser ablation $\mathrm{U}-\mathrm{Pb}$ zircon geochronology through robust downhole fractionation correction. Geochemistry, Geophysics, Geosystems 11: Q0AA06. doi: 10.1029/2009GC002618.

Paxman, G.J.G.; Jamieson, S.S.R.; Hochmuth, K.; Gohl, K.; Bentley, M. J.; Leitchenkov, G.; Ferraccioli, F. 2019. Reconstructions of Antarctic topography since the Eocene-Oligocene boundary. Palaeogeography, Palaeoclimatology, Palaeoecology 535: 109346. doi: 10.1016/j.palaeo.2019.109346.

Pérez, L.F.; Hernández-Molina, F. J.; Lodolo, E.; Bohoyo, F.; Galindo-Zaldívar, J.; Maldonado, A. 2019. Oceanographic and climatic consequences of the tectonic evolution of the southern scotia sea basins, Antarctica. Earth-Science Reviews 198: 102922. doi: 10.1016/j.earscirev.2019.102922.

Powell, A.J. 1992. A Stratigraphic Index of Dinoflagellate Cysts. Chapman and Hall: 290 p. London.

Powell, A.J.; Brinkhuis, H.; Bujak, J.P. 1996. Upper Paleocene-lower Eocene dinoflagellate cyst sequence biostratigraphy of southeast England. In Correlation of the Early Paleogene in Northwest Europe (Knox, R.W.O.; Corfield, R.M.; Dunay, R.E.; editors). Geological Societey of Lndon Special Publication 101 (1): 145-183.

Prebble, J.G.; Crouch, E.M.; Carter, L.; Cortese, G.; Bostock, H.; Neil, H. 2013. An expanded modern dinoflagellate cyst dataset for the Southwest Pacific 
and Southern Hemisphere with environmental associations. Marine Micropaleontology 101: 33-48.

Pross, J.; Schmiedl, G. 2002. Early Oligocene dinoflagellate cysts from the Upper Rhine Graben (SW Germany): paleoenvironmental and paleoclimatic implications. Marine Micropaleontology 45: 1-24.

Pross, J.; Houben, A.J.P.; Simaeys, S.V.; Williams, G.L.; Kotthoff, U.; Coccioni, R.; Wilpshaar, M.; Brinkhuis, H. 2010. Umbria-Marche revisited: A refined magnetostratigraphic calibration of dinoflagellate cyst events for the oligocene of the Western Tethys. Review of Palaeobotany and Palynology 158: 213-235.

Quattrocchio, M.E. 2009. Paleogene dinoflagellate cysts from Punta Prat, southern Chile. Palynology 33: $141-156$.

Raine, J.I.; Askin, R.A.; Crouch, E.M.; Hannah, M.J.; Levy, R.H.; Wrenn, J.H. 1997. Palynomorphs. In Southern Ocean Late Cretaceous/Early Cenozoic Biostratigraphic Datums (Hannah, M.J.; Raine, J.I.; editors). Institute of Geological and Nuclear Sciences, Scientific Report 97: 25-33.

Sauermilch, I.; Whittaker, J.M.; Bijl, P.K.; Totterdell, J.M.; Jokat, W. 2019. Tectonic, Oceanographic, and Climatic Controls on the Cretaceous-Cenozoic Sedimentary Record of the Australian-Antarctic Basin. Journal of Geophysical Research, Solid Earth 124 (8): 7699-7724.

Scher, H.D.; Martin, E.E. 2006. Timing and Climatic Consequences of the Opening of Drake Passage. Science 312: 428-430.

Sernageomin, 2003. Mapa Geológico de Chile: versión digital. Servicio Nacional de Geología y Minería, Publicación Geológica Digital, No. 4 (Cd-Rom). Santiago.

Seton, M.; Müller, R.D.; Zahirovic, S.; Gaina, C.; Torsvik, T.; Shephard, G.; Talsma, A.; Gurnis, M.; Turner, M.; Maus, S.; Chandler, M. 2012. Global continental and ocean basin reconstructions since 200 Ma. Earth-Science Reviews 113: 212-270.

Sijp, W.P.; von der Heydt, A.S.; Dijkstra, H.A.; Flögel, S.; Douglas, P.M.J.; Bijl, P.K. 2014. The role of ocean gateways on cooling climate on long time scales. Global and Planetary Change 119: 1-22.

Sijp, W.P.; Von Der Heydt, A.S.; Bijl, P.K. 2016. Model simulations of early westward flow across the Tasman Gateway during the early Eocene. Climate of the Past 12: 807-817.

Sláma, J.; Košler, J.; Condon, D.J.; Crowley, J.L.; Gerdes, A.; Hanchar, J.M.; Horstwood, M.S.A.; Morris, G.A.; Nasdala, L.; Norberg, N.; Schaltegger, U.; Schoene, B.; Tubrett, M.N.; Whitehouse, M.J. 2008. Plešovice
zircon-A new natural reference material for $\mathrm{U}-\mathrm{Pb}$ and Hf isotopic microanalysis. Chemical Geology 249: 1-35.

Sliwinska, K.K.; Abrahamsen, N.; Beyer, C.; BrüningsHansen, T.; Thomsen, E.; Ulleberg, K.; HeilmannClausen, C. 2012. Bio-and magnetostratigraphy of Rupelian-mid Chattian deposits from the Danish land area. Review of Palaeobotany and Palynology 172: 48-69.

Sluijs, A.; Brinkhuis, H. 2009. A dynamic climate and ecosystem state during the Paleocene-Eocene Thermal Maximum: inferences from dinoflagellate cyst assemblages on the New Jersey Shelf. Biogeosciences 6: 1755-1781.

Sluijs, A.; Brinkhuis, H.; Stickley, C.E.; Warnaar, J.; Williams, G.L.; Fuller, M. 2003. Dinoflagellate cysts from the Eocene-Oligocene transition in the Southern Ocean: Results from ODP Leg 189. In Proceedings of the Ocean Drilling Program (Exon, N.F.; Kennett, J.P.; Malone, M.J.; editors). Scientific Results 189: 1-42.

Sluijs, A.; Pross, J.; Brinkhuis, H. 2005. From greenhouse to icehouse; organic walled dinoflagellate cysts as paleoenvironmental indicators in the Paleogene. Earth-Science Reviews 68: 281-315.

Somoza, R.; Ghidella, M.E. 2012. Late Cretaceous to recent plate motions in western South America revisited. Earth and Planetary Science Letters 331: 152-163.

Stickley, C.E.; Brinkhuis, H.; Schellenberg, S.A.; Sluijs, A.; Röhl, U.; Fuller, M.; Grauert, M.; Huber, M.; Warnaar, J.; Williams, G.L. 2004. Timing and nature of the deepening of the Tasmanian Gateway. Paleoceanography 19: PA4027. doi: 10.1029/2004PA001022.

Sylvester, P.J.; Ghaderi, M. 1997. Trace element analysis of scheelite by excimer laser ablation-inductively coupled plasma-mass spectrometry (ELA-ICP-MS) using a synthetic silicate glass standard. Chemical Geology 141: 49-65.

Thomas, C. 1949. Geology and petroleum explorations in Magallanes Province, Chile. American Association of Petroleum Geologists, Bulletin 33: 1553-1578.

Tocher, B.A.; Jarvis, I. 1996. Dinoflagellate cyst distributions and the Albian-Cenomanian boundary (midCretaceous) at Cordebugle, NW France and Lewes, southern England. Journal of Micropalaeontology 15: 55-67.

Torres Carbonell, P.J.; Dimieri, L.V.; Martinioni, D.R. 2013. Early foreland deformation of the Fuegian Andes (Argentina): Constraints from the strain analysis of 
Upper Cretaceous-Danian sedimentary rocks. Journal of Structural Geology 48: 14-32.

Torres Carbonell, P.J.; Dimieri, L.V.; Olivero, E.B.; Bohoyo, F.; Galindo-Zaldívar, J. 2014. Structure and tectonic evolution of the Fuegian Andes (southernmost South America) in the framework of the Scotia Arc development. Global and Planetary Change 123: 174-188.

Van Mourik, C.A.; Brinkhuis, H. 2005. The Massignano Eocene-Oligocene golden spike section revisited. Stratigraphy 2: 13-30.

Van Mourik, C.A.; Brinkhuis, H.; Williams, G.L. 2001. Mid-to late Eocene organic-walled dinoflagellate cysts from ODP Leg 171B, offshore Florida. Geological Society of London Special Publication 183: 225-251.

Warnaar, J. 2006. Climatological implications of Australian-Antarctic separation. Ph.D. Thesis (Unpublished). Laboratory of Palaeobotany and Palynology Contributions Series No. 22: 143 p. Utrecht.

Warnaar, J.; Bijl, P.K.; Huber, M.; Sloan, L.C.; Brinkhuis, H.; Röhl, U.; Sriver, R.; Visscher, H. 2009. Orbitally forced climate changes in the Tasman sector during the Middle Eocene. Palaeogeography, Palaeoclimatology, Palaeoecology 280: 361-370.
Williams, G.L.; Stover, L.E.; Kidson, E.J. 1993. Morphology and stratigraphic ranges of selected Mesozoic-Cenozoic dinoflagellate taxa in the Northern Hemisphere. Geolological Survey of Canada 92 (10): 1-137.

Williams, G.L.; Fensome, R.A.; MacRae, R.A. 2017. DINOFLAJ3. American Association of Stratigraphic Palynologists, Data Series 2. http://dinoflaj.smu.ca/ dinoflaj3.

Wilson, D.S.; Jamieson, S.S.R.; Barrett, P.J.; Leitchenkov, G.; Gohl, K.; Larter, R.D. 2012. Antarctic topography at the Eocene-Oligocene boundary. Palaeogeography, Palaeoclimatology, Palaeoecology 335-336: 24-34. doi: 10.1016/j.palaeo.2011.05.028.

Wrenn, J.H.; Beckman, S.W. 1982. Maceral, total organic carbon, and palynological analyses of Ross Ice Shelf Project Site J9 cores. Science 216: 187-189.

Wrenn, J.H.; Hart, G.F. 1988. Paleogene dinoflagellate cyst biostratigraphy of Seymour Island, Antarctica. Geological Society of America, Memoires 169: 321-447.

Zegarra, M.; Helenes, J. 2011. Changes in Miocene through Pleistocene dinoflagellates from the Eastern Equatorial Pacific (ODP Site 1039), in relation to primary productivity. Marine Micropaleontology 81: 107-121. 


\section{PLATES}
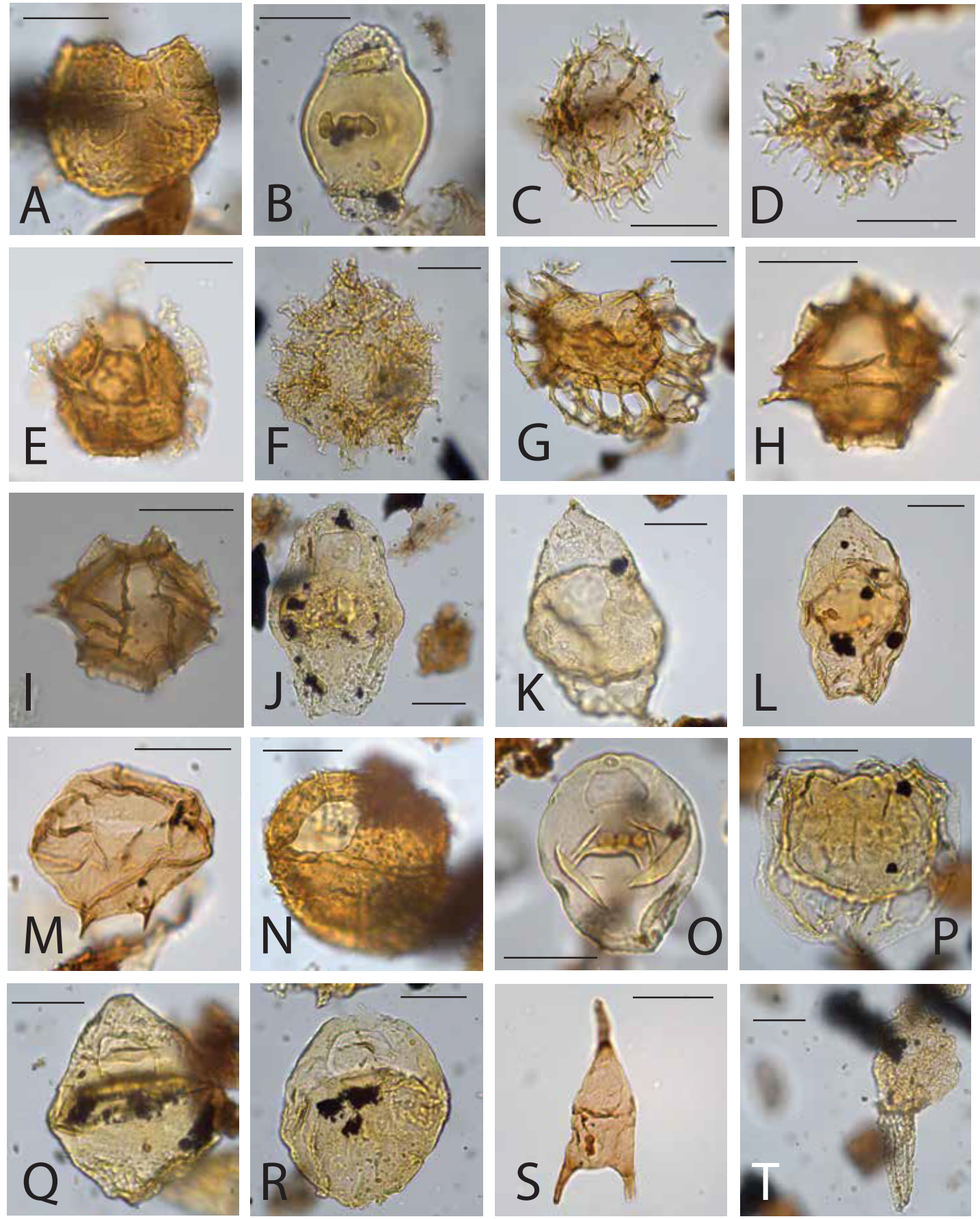

PLATE 1. A. Alisocysta margarita Chorrillo Chico (CC)3; B. Amphidiadema denticulata, Fuentes (FUEN)1; C. Apectodinium homomorphum, Agua Fresca (AGFR)3; D. Apectodinium sp., AGFR1; E. Cassidium filosum, Río Pérez (RP)13; F. Circulodinium compactum, FUEN1; G. Glaphyrocysta pastielsii, RP9; H-I. Impagidinium sp., RP13; J. Isabelidinium bakeri, FUEN1; K. Isabelidinium bakeri, FUEN3; L. Isabelidinium bakeri, RP6; M. Lejeunecysta fallax, Pecket Mine (PM)6; N. Leptodinium pustulatum, CC3; O. Manumiella seymourense, FUEN3; P. Membranophoridium perforatum, RGP3-21-1-79; Q. Nelsoniella aceras, FUEN1; R. Nelsoniella aceras, FUEN1; S. Octodinium askiniae, RGP3-24-1-1; T. Odontochitina cribropoda, FUEN1; Scale bar $=25 \mu \mathrm{m}$. 

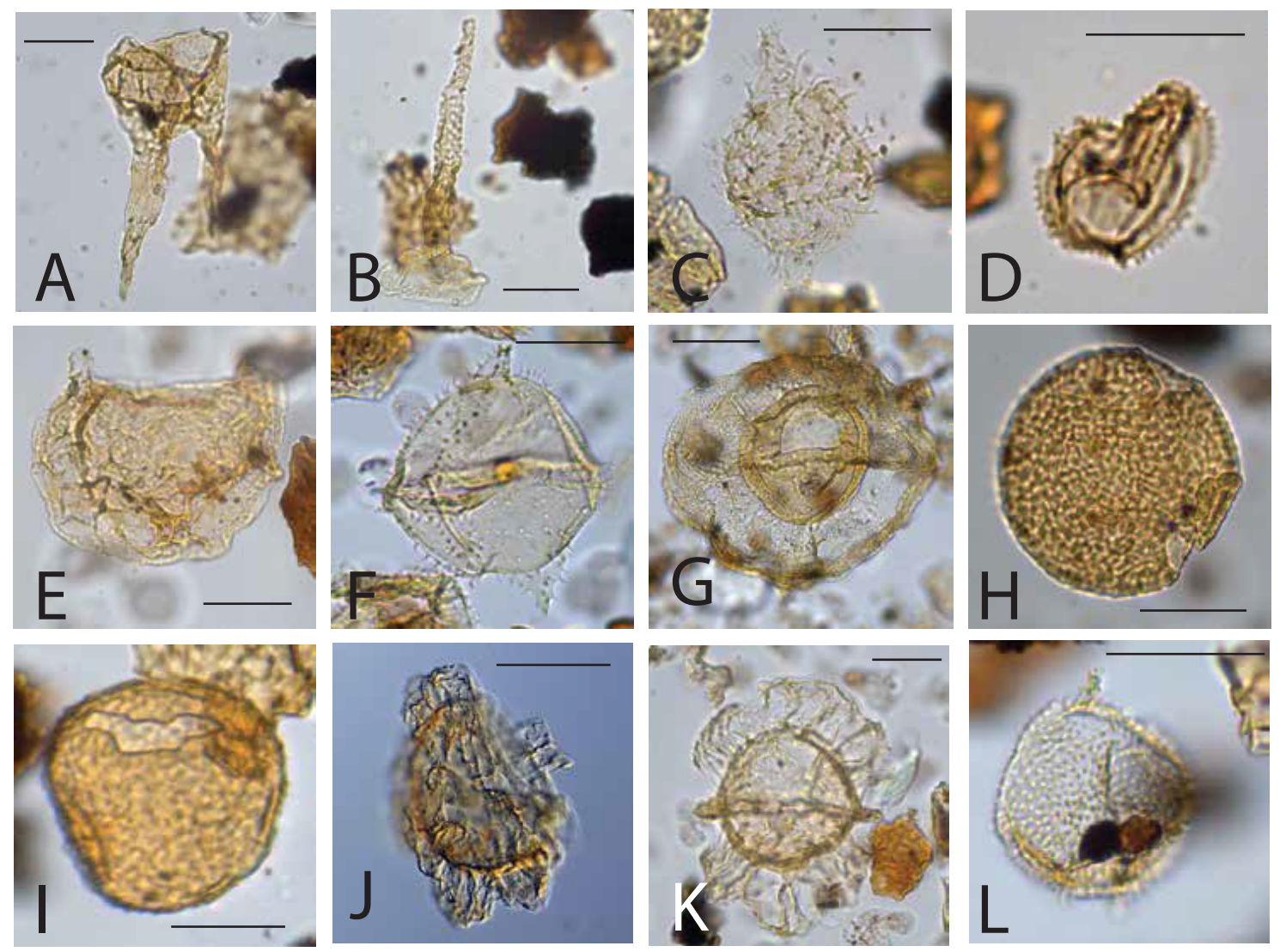

PLATE 2. A. Odontochitina operculata, FUEN1; B. Odontochitina perforata, FUEN1; C. Palaeohystrichophora infusorioides, FUEN1; D. Selenopemphix brinkhuisii Bijl et al., 2018, PM8; E. Senoniasphaera inornata, FUEN3; F. Spinidinium macmurdoense, Río Los Palos (LP)14; G. Thalassiphora pelagica, SELK65-7-1-10; H. Trithyrodinium vermiculatum, FUEN3; I. Trithyrodinium vermiculatum, FUEN3; J. Turbiosphaera filosa, T-1-20-2-70; K. Turbiosphaera sagena, LP14; L. Vozzhennikovia apertura, LP4. Scale bar $=25 \mu \mathrm{m}$. 